\title{
THE AFFECTIVE ROOTS OF RESOURCE HETEROGENEITY: HOW FOUNDERS' EMOTION REGULATION HELPS CREATE SOCIAL RESOURCES IN STARTUPS
}

\author{
Christoph Zott \\ Quy Huy
}




\title{
THE AFFECTIVE ROOTS OF RESOURCE HETEROGENEITY: HOW FOUNDERS' EMOTION REGULATION HELPS CREATE SOCIAL RESOURCES IN STARTUPS
}

\author{
Christoph Zott ${ }^{1}$
}

Quy Huy ${ }^{2}$

\begin{abstract}
Where do firms' heterogeneous resources come from? Our qualitative, inductive study of nascent firms over seven years revealed that founders' differential use of emotion regulation behaviors can explain the differential creation of social resources at the firm level. We found that founders' emotion regulation behaviors cluster around three themes: 1) the founder's temporal perspective (short-term versus long-term); 2) the nature of founder benefits (economic versus emotional rewards), and 3) the target of founder attention (self versus others). We theorize that founders' emotion regulation behaviors based on these themes influence the incentives of founders and stakeholders and thereby enable the creation of valuable and difficult-to-imitate social resources for their ventures. Social resources include discretionary support provided by founders and stakeholders, as well as founder persistence and stakeholder willingness-to-help. Our study contributes to the strategy literature by showing empirically the link between specific emotion regulation behaviors and the emergence of resource heterogeneity at the firm level. It specifically contributes to resource-based theory by separating the theory's main assumptions and outcomes, reducing concerns about potential tautology.
\end{abstract}

Keywords: Resource heterogeneity, resource-based view, emotion regulation, entrepreneurship.

Note: Both authors contributed equally to this article. We would like to thank Sharon Alvarez, Africa Ariño, Russ Coff, Laurence Capron, Fabrizio Ferraro, Hakan Ener, Anita McGahan, Pinar Ozcan, Julia Prats, Claus Rerup, Joan Enric Ricart, Kaye Schoonhoven, and Marco Tortoriello for their feedback on earlier drafts of this paper. We gratefully acknowledge financial support from IESE and from the Kolendorf Fund for Entrepreneurship at INSEAD. We would like to thank César Guzmán-Concha and Wendy Smith for their valuable research assistance, and MarieFrançoise Piquerez and Silvia Munne Gustems for their excellent administrative support.

\footnotetext{
${ }^{1}$ Professor of Entrepreneurship, IESE Business School

${ }^{2}$ Professor, INSEAD
} 


\section{THE AFFECTIVE ROOTS OF RESOURCE HETEROGENEITY: HOW FOUNDERS' EMOTION REGULATION HELPS CREATE SOCIAL RESOURCES IN STARTUPS}

\section{Introduction}

Where do the differential resources that are assumed to provide competitive advantage to firms come from (Peteraf and Barney, 2003)? Understanding the causes of firms' resource heterogeneity is of great interest to scholars who view competitive advantage through a resource-based lens, because resource heterogeneity is associated with differential value creation and firm rents (Amit and Schoemaker, 1993; Barney, 1991; Peteraf, 1993). As Peteraf and Barney (2003, p. 311) noted, "Without differentiable resources, resource-based theory makes no contribution of its own and ceases to be a theory discrete from other analytical tools." Understanding the causes of resource heterogeneity is also important to scholars interested in why firms differ and why that matters (e.g., Nelson, 1991; Rumelt, Schendel, and Teece, 1994). In this paper, we seek to enrich a cognition-focused understanding of the origins of firms' resource heterogeneity by bringing in affect through founders' ER behaviors. Emotion regulation (ER) behaviors maintain or modify emotional reactions in order to achieve goaldirected outcomes (Gross and John, 2003; Matsumoto et al., 2008).

Although resource heterogeneity constitutes a central tenet of resource-based theory (Peteraf, 1993), there has been insufficient scholarly exploration of the various conditions under which it can arise, perhaps because they were originally thought to lie outside of the scope of early resource-based theory research. As a result, our knowledge of the origins of resource heterogeneity is partly based on theoretical speculation about exogenous factors, such as chance events or environmental influences, path dependence, governmental largess and unevenly distributed property rights (e.g., Barney, 1986; Dierickx and Cool, 1989; Nelson, 1991; Foss and Foss, 2005; Peteraf and Barney, 2003).

However, resource heterogeneity can also be an endogenous creation by economic actors (Mahoney and Pandian, 1992). These endogenous factors have largely been linked to managers' cognitive processes, such as bounded rationality in search, decision-making, and learning (Castanias and Helfat, 2001; Nelson, 1991; Williams, 1994), cognitive development paths (Helfat 
and Peteraf, 2009), heuristics (Busenitz and Barney, 1997) and framing (Alvarez and Busenitz, 2001). As a result of these cognitive processes, managers "choose somewhat different strategies ... [that] in turn will lead to firms having different structures and different core capabilities" (Nelson, 1991, p. 69). Although scholars generally recognize that "firms are different because of the actions of managers" (Williams, 1994, p. 244) - actions that can be shaped by cognition as well as by affect - we know relatively little about how affect influences the endogenous creation of resources and the emergence of resource heterogeneity among firms. The strategy literature has yet to develop a fine-grained understanding of various kinds of affect-related managerial actions that produce resource heterogeneity. We therefore ask the following research questions: What specific ER behaviors do founders use, and how and why do these behaviors differentially affect resource creation in nascent firms?

Our study follows earlier suggestions that exploration of the intersection between research into strategy and entrepreneurship could provide rich insights (Hitt and Ireland, 2000). Specifically, studying firm founders' behaviors could shed further light on the creation of resources and capabilities in firms (Alvarez and Barney, 2007; Alvarez and Busenitz, 2001; Barney, Wright and Ketchen, 2001). In addition, scholars have recently turned their attention to the potential importance of affect for firm creation (Baron, 2008; Cardon, Wincent, Singh, and Drnovsek, 2009; Perry-Smith and Coff, 2009).

Extant theories on the role of affect, and specifically ER, for resource creation are not sufficiently developed to guide the formulation of precise hypotheses for testing purposes: there are many possible kinds of ER behavior that entrepreneurs can use and it is not clear which they actually practice (if any at all). More importantly, the links between specific ER behaviors and resource creation outcomes are neither well understood nor empirically established. We therefore conducted a longitudinal, inductive (Eisenhardt, 1989; Yin, 1994) study of six new ventures where founders exhibited varying levels of ER behaviors.

Our analysis of the data revealed that founders' differential use of ER at the personal level can explain differential resource creation (resource heterogeneity) at the firm level. Specifically, our findings reveal that founders of new firms can foster the creation of what we call social resources $^{1}$ - e.g., discretionary support and persistence from founders and willingness-to-help from venture stakeholders - by enacting distinct modes (i.e., how certain actions are performed) and types (i.e., what actions are performed) of ER. Interestingly, we found that these behaviors cluster around three themes that relate to the process of organization building and involve: 1) the founder's temporal perspective for organization building (short- versus long-term focus); 2) the nature of founder rewards (economic versus emotional), and 3) the target of founder attention (self versus others). We theorize that these ER behaviors influence the incentives of founders and stakeholders and so contribute to the creation of valuable and difficult-to-imitate social resources for their ventures.

\footnotetext{
${ }^{1}$ We use the term "social resources" in this paper to acknowledge their origin, namely venture founders and stakeholders and the social interactions among them, and to distinguish them from other types of resources, such as financial or physical resources. Social resources (e.g., the support and persistence of founders, the trust and effort of employees, or the goodwill and support of investors) are akin to organizational capital such as firm culture (Barney, 1997, p. 156).
} 
Our study contributes both empirically and theoretically to the strategy literature. We show empirically that the emergence of resource heterogeneity within a pool of young firms can have "affective roots." Indeed, our study may be the first to establish an empirical link between specific affect-related personal behaviors of entrepreneurs and associated resource creation outcomes at the firm level. Furthermore, following Barney's (2001) conjecture that "resourcebased models of strategic advantage may need to be augmented by theories of the creative and entrepreneurial process" (p. 53), our study provides two important theoretical insights. First, we illuminate the "front-end" part of resource-based theory, as articulated by Peteraf and Barney (2003). Our empirically grounded model shows how resource heterogeneity is not just a starting point of resource-based theorizing, but can result endogenously from founders' affect-related actions. Since our model is predictive and offers clearly defined, operationalizable constructs, it could enhance the predictive power and definitional clarity of resource-based theory.

Second, by treating managers' ER behaviors as independent variables, and deriving from them firms' endowments with heterogeneous resources, we increase the distance between the main assumptions and outcomes of resource-based theory, thus reducing concerns about potential tautology (e.g., resource characteristics defined in terms of their performance outcomes). Our theory thus suggests a potential way in which resource-based scholars can avoid the risk of circular reasoning (e.g., "valuable resources lead to value") that was noted by Priem and Butler (2001).

The remainder of this paper is organized as follows. First, we briefly review the literature on ER and its implications for firm-level outcomes, specifically resource creation, to highlight the relevance of adopting an ER lens for understanding better the origins of firm-level resourcebased strategy. We then describe our research method and present our findings. We integrate the empirical insights into a model that articulates the relationships between ER and resource heterogeneity. In the discussion section, we present a potential theoretical mechanism - the reconciliation of tensions to create incentives for founders and stakeholders - that could explain why ER fosters resource creation, and discuss the implications of our findings for resource-based theory. Finally, we highlight avenues for future research.

\section{Emotion Regulation and Resource Creation}

A review of the relevant literatures gives us some understanding how ER may be important for founders' ability to create social resources for their nascent firms. Emotion regulation includes all of the conscious and unconscious efforts to increase, maintain, or decrease one or more components of an emotion (Gross, 1999). Emotion regulation actions are behaviors that deliberately maintain or modify self-emotional experiences to achieve specific goals (Gross and John, 2003; Côté, 2005). Emotions refer to bio-psychological systems that involve cognitive appraisal of specific situations in relation to one's goals and concerns, distinctive physiological reactions and action tendencies, and subjective experience including affect (Frijda, 1986; Ortony, Clore, and Collins, 1988). Emotions typically begin with appraisals or evaluations of events along such dimensions as causation (i.e., "is the event caused by other people or circumstances?") or degree of control (i.e., "how much control do I have over the situation?"). For example, events appraised as unpleasant and harmful to self and over which one feels having little control cause anxiety or fear (Roseman, 1991). Emotions are important to study in an organization-building context because they serve as motivators of behavior as well as having important social functions, such as informing others of one's internal states 
and intentions, evoking responses in others, and providing incentives for others (Keltner et al., 2003).

The entrepreneurial process can be replete with events, real or imagined, which are perceived as relevant and important to self (McMullen and Shepherd, 2006), and which can therefore elicit emotions (Lazarus, 1991). Some researchers have recognized the importance of founders' own emotional states, such as rapacity and greed (Webster, 1976), attachment to the venture (Comegys, 1976), or pride and shame (Goss, 2005a, 2005b). Other scholars have investigated or at least considered how founders deal with particular emotional states such as loneliness (Gumpert and Boyd, 1984), stress (Boyd and Gumpert, 1984), or grief (Shepherd, 2003). However, we know of very little, if any, systematic longitudinal field research on the various emotions that entrepreneurs experience, how they deal with these different emotions, and how this influences resource creation for their ventures, and hence, the emergence of resource heterogeneity.

Emerging research on emotion regulation that explores the links between emotion regulation and organizational outcomes has remained largely theoretical, and this research has focused very little on matters of concern to strategic management or entrepreneurship. What we know is that individuals differ in their ability to regulate their emotions, some choosing more successful strategies than others, which allow them to attain desired emotional states and outcomes that are beneficial to their social adaptation and long-term well-being (Mayer and Salovey, 1997). Emotion regulation thus represents a key attribute of emotional intelligence (Gross and John, 2003). Research has shown that the ways in which people regulate their emotions have both intrapersonal (e.g., subjective well-being and stress) and interpersonal effects (pro-social behavior and closer social relationships with others) (e.g., Côté, 2005; Eisenberg, 2000; Lopes et al., 2005). Intrapersonal effects could be associated with resource creation from self (founder), whereas interpersonal effects could facilitate resource creation from others (venture stakeholders other than founders).

Regarding the latter (interpersonal effects), emotion regulation influences one's emotional expression and behavior and shapes the emotional tone of the social encounters (Hochschild, 1983; Grandey, 2003). Emotions are subconsciously contagious in a social milieu (Hatfield et al., 1994) and influence the quality of social interaction. An entrepreneur's inappropriate outburst of anger in front of a potential investor could put an end to this new relationship (Lopes et al., 2005). The quality of social interaction influences the odds of creating resources from various stakeholders. An entrepreneur who regulates her own emotions so as to display calm or pleasant emotions, for example, is likely to elicit favorable responses from others whereas a display of agitated emotions such as anger and fear could drive potential supporters away (Furr and Funder, 1998).

Emotion regulation also matters at the firm-level because it can have intrapersonal effects and influence the entrepreneur's quality of thinking and decision-making with regard to the venture (e.g., avoid making important decisions under highly agitated emotional states) (Fredrickson, 1998). Different emotions can influence entrepreneurs' subsequent thinking and action in different ways (Baron, 2008; Lerner and Keltner, 2001). 
To the best of our knowledge, however, empirical research has under-explored what actions founders of new organizations take to regulate the variety of positive and negative emotions that are elicited by the challenging process of building new organizations, and how and why differences in emotion regulation influence their success in creating a variety of social resources that are critical to building new organizations. This is what we propose to do with our longitudinal field research.

Adjacent empirical studies that focus specifically on entrepreneurs' affect, moreover, have produced equivocal results. For example, researchers have examined the affect-related constructs of "expressiveness" - the ability to express one's emotions and feelings (Baron and Markman 2000, 2003) - and "passion" (e.g., Baum, Locke, and Smith 2001; Baum and Locke, 2004; Chen, Yao, and Kotha, 2009). Baum and Locke (2004) argued that "passion" influences founders' competence and motivation, positively impacting venture development. But Chen et al. (2009) found that "passion" does not matter for resource mobilization, echoing previous conjectures about investors' preference for cognitive evaluation criteria (Kaplan and Strömberg, 2003; MacMillan et al., 1985; Shepherd, 1999).

\section{Methods}

\section{Sample Selection and Data Collection}

As the extant literatures are insufficiently developed to allow the formulation of precise hypotheses to test the extent to which founders perform ER, the kinds of ER they practice, and associated outcomes, we have used qualitative, inductive field research. According to Suddaby (2006), this grounded method is best suited for research questions that examine the process by which actors interpret and construct meaning out of intersubjective experience. Pratt (2009) further noted that qualitative research is best suited to addressing "how" (as opposed to "how much"), and understanding the world from the perspective of those studied, and examining and articulating processes. We therefore conducted a longitudinal and theory-building field study of several nascent United Kingdom-based companies, following a case comparison methodology elaborated by qualitative researchers, including Eisenhardt and Graebner (2007).

To identify entrepreneurs who had recently launched new firms or were in the process of creating them, we searched a United Kingdom business school's database of alumni who had become involved in entrepreneurial ventures after graduation. The resulting list contained 230 people, whom we contacted by e-mail to explain the purpose of our research. We asked for entrepreneurs who 1) had launched a company within the past 18 months or were planning to do so in the next six months; 2) had their headquarters in the Greater London area, and 3) were willing to participate in a research project that might involve a substantial time commitment. We guaranteed participants complete confidentiality and anonymity. We aimed to study entrepreneurs in the early stages of creating their companies for two reasons: first, we wanted to avoid sampling based on outcomes (e.g., survival); and second, few researchers have systematically explored these early stages. We focused on a confined geographical area to minimize sample variation due to environmental factors (e.g., sociopolitical context, business climate, available resources). 
An initial screening process produced 26 ventures. We did not expect significant bias due to non-response during this selection stage. First, we intended to study entrepreneurial behavior broadly - our focus on the regulation of emotions and its importance for entrepreneurial outcomes emerged only during our iterative data analysis. Second, most of the ventures in our sample started between 1999 and 2001 and were at such early stages of development that predictions about their eventual success were premature.

We recorded entrepreneurial behavior (in real time and retrospectively) mainly by interviewing the founders. Most had graduated from the same top-tier business school, had high GMAT test scores (around 700), had an average of about five years' professional experience before enrolling in the MBA program, and could access the school's vast and high-powered alumni network. In this way, our selection controlled for aspects of human capital, such as educational background, analytical skill and managerial experience, as well as aspects of social capital - all of which are usually sources of heterogeneity in entrepreneurial ventures. We thus followed Gartner's (1985) suggestion to increase the homogeneity of entrepreneurial sub-groups and look for variations within them to develop mid-range theories.

Beginning in February 2002, we conducted face-to-face interviews, mostly at work sites, with all 26 entrepreneurs. We established a personal rapport with them individually. Each interview in the first round lasted between one and two hours. The second round of interviews took place between October and December 2002, the third in October-November 2003, the fourth in January-February 2005, and the fifth in June-July 2009. During the first round of interviews in particular, we asked the founders to provide us with comprehensive accounts of their activities since the earliest days of their ventures. We asked open-ended questions and prompted respondents to provide concrete examples to minimize recall and decontextualized rationalization biases. Typical questions on emotion regulation were: Can you tell us about some emotionally high and low moments in the last period? How did you deal with them? What consequences, if any, did this have on your own thinking and actions, and those of people you interacted with?

In analyzing more deeply various ER behaviors and how they influenced organization-level outcomes, we followed Eisenhardt's (1989, p. 537) recommendation for a theoretical sampling approach that involves between four and ten "extreme" cases in which the phenomenon of interest is "transparently observable." For these cases, we sought to obtain confidential access to a variety of stakeholders to validate and contextualize founders' accounts. Interviews with these third parties lasted between 15 minutes and two hours, depending on people's availability and propensity to elaborate their perspectives. Table 1 presents short descriptions of these six focal cases (names of the companies and respondents are disguised to ensure confidentiality). 


\section{Table 1}

Cases and Interviews per Case

\begin{tabular}{|c|c|c|c|c|}
\hline Case & Business Description & $\begin{array}{l}\text { Founder } \\
\text { Interviews }\end{array}$ & $\begin{array}{l}\text { Interviews } \\
\text { with Others }\end{array}$ & $\begin{array}{c}\text { Total } \\
\text { Interviews }\end{array}$ \\
\hline BUDGET & $\begin{array}{l}\text { Formed in September } 2001 \text { to operate high-quality limited } \\
\text { service hotels. Develops sites for new budget motels in } \\
\text { partnership with financiers and brand owners. Negotiates } \\
\text { license agreement, interprets and implements brand } \\
\text { standards, and optimizes required resources. Manages the } \\
\text { operations (e.g., recruits and trains staff, performs sales and } \\
\text { marketing) of the newly built motels under well-known } \\
\text { brands, such as Holiday Inn, without owning the properties. } \\
\text { Opened first hotel in March } 2003 \text {, and by January } 2005 \text { had } \\
17 \text { hotels under management (including } 11 \text { from an } \\
\text { acquisition). Backed by financial and strategic investors. }\end{array}$ & 5 & $\begin{array}{l}11 \\
\text { (co-founder, } 2 \\
\text { senior } \\
\text { executives, } 2 \\
\text { middle } \\
\text { managers, } \\
\text { lawyer, } \\
\text { chairman of the } \\
\text { board, investor) }\end{array}$ & 16 \\
\hline CONSULT & $\begin{array}{l}\text { Founded in May } 2000 \text { by former partners of a well-known } \\
\text { large global IT consulting firm. Provides IT-supported } \\
\text { consulting services to large and mid-sized companies. } \\
\text { Specializes in procurement (e.g., outsourcing) solutions, but } \\
\text { also offers recruiting services. Over five years, grew to over } \\
40 \text { strategy, business process and IT consultants. Seed- } \\
\text { funded by business angels and founders' equity } \\
\text { contributions (in total about £300k), but grew mostly } \\
\text { organically (i.e., investments financed by firm's own } \\
\text { revenues). }\end{array}$ & 5 & $\begin{array}{l}5 \\
\text { (co-founder, } 2 \\
\text { employees, } 2 \\
\text { investors) }\end{array}$ & 10 \\
\hline DRINK & $\begin{array}{l}\text { Founded in September } 2002 \text { to build a whiskey distillery with a } \\
\text { production capacity of } 40,000 \text { cases per year. At the same } \\
\text { time, produces and markets a range of innovative white spirits } \\
\text { using only natural ingredients for consumers of alcoholic } \\
\text { beverages around the world. Funded by a large number of } \\
\text { private investors, as well as government subsidies. }\end{array}$ & 5 & $\begin{array}{l}8 \\
(2 \text { co-founders, } 2 \\
\text { employees, former } \\
\text { chairman of the } \\
\text { board, current } \\
\text { chairman) }\end{array}$ & 13 \\
\hline INCUBATE & $\begin{array}{l}\text { Founded in December 2000. Originally, aimed at helping large } \\
\text { companies develop new ventures. Then changed business } \\
\text { model to acquiring ailing on-line retail businesses (e.g., pet } \\
\text { food and gardening products), consolidating these businesses } \\
\text { and running them on a common IT infrastructure. After } \\
\text { consolidation, experienced modest growth rates (e.g., pet food } \\
\text { business grew to } 20 \text { employees). One of the founders } \\
\text { withdrew, others became involved part-time. Largely self- } \\
\text { funded. }\end{array}$ & 4 & $\begin{array}{l}2 \\
\text { (co-founder, } \\
\text { wife) }\end{array}$ & 6 \\
\hline INVEST & $\begin{array}{l}\text { Assembled team in January } 1998 \text { and closed first deal in } \\
\text { September that year. Provides financial services and } \\
\text { specialist financing for European early-stage hi-tech } \\
\text { companies, especially in biotech, computing, and } \\
\text { communication infrastructures. After several years of } \\
\text { operations, in } 2002 \text { essentially had to wind down first fund } \\
\text { and restart by raising a new fund (size: over } € 100 \text { million) } \\
\text { from new investors with a new management team after }\end{array}$ & 5 & $\begin{array}{l}3 \\
(2 \text { senior } \\
\text { executives, } \\
\text { former investor } \\
\text { and board } \\
\text { member) }\end{array}$ & 8 \\
\hline
\end{tabular}

${ }^{2}$ Others include co-founders. The interview count in each cell of this column may be greater than the total number of stakeholders because some stakeholders provided more than one interview. 


\begin{tabular}{|c|c|c|c|c|}
\hline Case & Business Description & $\begin{array}{c}\text { Founder } \\
\text { Interviews }\end{array}$ & $\begin{array}{c}\text { Interviews } \\
\text { with Others }\end{array}$ & $\begin{array}{c}\text { Total } \\
\text { Interviews }\end{array}$ \\
\hline & $\begin{array}{l}\text { some of the original founders had left. As a result, changed } \\
\text { the name of the company. Funded by third-party institutional } \\
\text { money from financial sponsors such as the European } \\
\text { Investment Fund and well-known investment banks. }\end{array}$ & & & \\
\hline TECH & $\begin{array}{l}\text { Founded in December } 1999 \text { to provide wireless telephony } \\
\text { solutions for offices and factories. Develops technology that } \\
\text { turns mobile phones and headsets into extensions of } \\
\text { corporate networks and gives portable data devices and } \\
\text { smart phones access to local area networks. Grew to more } \\
\text { than } 40 \text { staff (mostly engineers) within three years of } \\
\text { founding, yet failed to produce a commercially viable } \\
\text { product. Backed with more than } £ 10 \text { million by venture } \\
\text { capital firms. }\end{array}$ & 5 & $\begin{array}{l}8 \\
\text { (co-founder, } \\
\text { former } \\
\text { chairman of } \\
\text { board, senior } \\
\text { executive, } \\
\text { middle } \\
\text { manager, wife) }\end{array}$ & 13 \\
\hline TOTAL & & 29 & 37 & 66 \\
\hline
\end{tabular}

The ventures in this sample are active in many industries, including hotel management (BUDGET), food production (DRINK), consulting services (CONSULT), online retailing (INCUBATE), financial services (INVEST), and communications (TECH). Thus, our sample covers a number of diverse industries. All entrepreneurial teams were first-time founders, apart from the founder of DRINK, who had limited entrepreneurial experience in a different industry.

During private interviews, these founders were essentially making sense of their reactions to events they considered important to them and how they dealt with them. The events and emotions they reported were often of an enduring nature and could be reproduced mentally in a relatively reliable manner (e.g., feeling worried about investors' reluctance to fund their ventures), as opposed to less consequential, episodic emotional experiences that could be forgotten quickly (e.g., reporting on being upset by a computer malfunction that was fixed a few days later) (see Robinson and Clore, 2002). Regular interviews with each founder over seven years should also reduce recall and ex-post rationalization biases of known outcomes. As noted, we also interviewed people who interacted frequently with the founders, such as their close partners, direct reports, board members, and key investors to allow us to validate their and the founders' accounts. All of these steps enabled us to triangulate our findings to build stronger interpretations (Yin, 1994).

Focusing on these six cases helped us reach a satisfactory level of theoretical saturation; the 20 other cases we considered did not yield any new important theoretical insights with regard to our research questions. For instance, we did not find evidence of new categories of emotion regulation behaviors or other important entrepreneurial outcomes that were linked to founders' ER.

\section{Data Analysis}

We used the case-replication method, in which cases serve as independent experiments that either confirm or reject emerging insights (Eisenhardt, 1989). We analyzed our data in six broad steps. First, we noted the prevalence of emotional experiences in the context of building new companies. Most entrepreneurs reported emotionally intense situations. Some even referred to the process of creating a new business as an "emotional rollercoaster." We found, however, that there were stark differences in the way entrepreneurs described their emotional experiences: some 
presented very richly textured accounts of emotional situations and how they dealt with them, whereas others' descriptions were very terse-even when describing situations, like firing a partner, that could have been intensely emotional. This first step helped us focus our attention on the six extreme cases described in Table 1, with noticeably rich or terse founders' accounts of emotions (the first and last three firms, respectively).

Second, we examined the founders' accounts more closely and coded the "quotes" in which they clearly expressed emotions they had experienced themselves - for example, joy, frustration, anger, and fear. We focused on those quotes that clearly involved efforts to regulate (i.e., elicit or modify) their own emotions.

Initially, we coded some data together to develop a list of empirically grounded ER behaviors to generate first-order concepts (Van Maanen, 1979) that describe specific ER behaviors. Table 2 illustrates how we coded various quotes (column 3) using different first-order concepts (column 1) and the associated definition of each of these concepts (column 2). Each of us independently went through these interviews to code various ER behaviors according to our initial shared definitions, and to identify any associated outcomes. We then compared our codings and discussed any disagreements we had. If we could not reach consensus on either ER behavior and/or its link to specific outcomes, we simply dropped the quote. Obviously, several coding iterations were performed as we refined our ER first-order concepts to increase their discriminate validity. As a result, the final coding agreement on the first-order concepts was 100 percent.

In the third step, we engaged in axial coding (Strauss and Corbin, 1998) to build up more abstract second-order themes that applied over multiple first-order concepts. This step yielded more abstract and robust descriptions involving two main "types" of emotion regulation behaviors: those associated with the founders' temporal perspective, such as short-term versus long-term focus, and those associated with the nature of the founders' rewards (economic or psychic). For example, we grouped the first-order concepts of "emotional expanding," "emphasizing emotional benefits," "eliciting pleasant emotions in venture development" under the second-order theme of "ER actions affecting the nature of founders' rewards" because they all refer to actions that focus on emotion-related rewards.

\section{Table 2}

Entrepreneurs' Emotion Regulation (ER) Actions

\begin{tabular}{|c|c|c|c|}
\hline Representative Quotes & First-order Concept Definition & $\begin{array}{c}\text { First-order } \\
\text { Concept Label }\end{array}$ & $\begin{array}{c}\text { Second- } \\
\text { order Theme }\end{array}$ \\
\hline $\begin{array}{l}\text { "I'm a bit bored at the moment. I want the } \\
\text { company to be growing... That's going to } \\
\text { give me the biggest excitement ever, } \\
\text { when we're recruiting heavily again and } \\
\text { we're building new parts of the } \\
\text { organization and we're winning work to } \\
\text { support that frequently." (CONSULT) }\end{array}$ & $\begin{array}{l}\text { Taking deliberate action to reduce } \\
\text { boredom that may creep in as the } \\
\text { development of the venture takes longer } \\
\text { than expected, or the venture moves into } \\
\text { a phase of stable slow growth or } \\
\text { stagnation. }\end{array}$ & $\begin{array}{l}\text { Managing } \\
\text { boredom from } \\
\text { slow venture } \\
\text { development }\end{array}$ & $\begin{array}{l}\text { Founder time } \\
\text { horizon }\end{array}$ \\
\hline $\begin{array}{l}\text { "I can see the light at the end of the } \\
\text { tunnel." (BUDGET) } \\
\text { "It's like looking for the signs of spring...if } \\
\text { there is external momentum being } \\
\text { generated, I keep going." (DRINK) }\end{array}$ & $\begin{array}{l}\text { Telling oneself }- \text { based partly on } \\
\text { substantive evidence, but more as a } \\
\text { statement of unsupported optimism - that } \\
\text { the venture's future prospects will be } \\
\text { better than its current ones. }\end{array}$ & $\begin{array}{l}\text { Rekindling of } \\
\text { hope regarding } \\
\text { venture } \\
\text { prospects }\end{array}$ & $\begin{array}{l}\text { Founder time } \\
\text { horizon }\end{array}$ \\
\hline
\end{tabular}




\begin{tabular}{|c|c|c|c|}
\hline Representative Quotes & First-order Concept Definition & $\begin{array}{c}\text { First-order } \\
\text { Concept Label }\end{array}$ & $\begin{array}{l}\text { Second- } \\
\text { order Theme }\end{array}$ \\
\hline $\begin{array}{l}\text { "I refused to give up. I got a new lease of } \\
\text { energy in terms of wanting to make } \\
\text { something happen with the business. For } \\
\text { the next two weeks I worked a hundred } \\
\text { hours a week, making just maybe a hundred } \\
\text { phone calls a day, very intensely, to try and } \\
\text { find investors. I worked like a dog. I just tried } \\
\text { to save the business." (TECH) }\end{array}$ & $\begin{array}{l}\text { In a context where founders are faced with } \\
\text { competing priorities or potential } \\
\text { distractions, or where there is a risk of } \\
\text { energy dispersion: making a deliberate } \\
\text { effort to apply, concentrate, or focus } \\
\text { emotional energy on conducting activities } \\
\text { that relate to building the organization (as } \\
\text { opposed to family, hobbies). }\end{array}$ & $\begin{array}{l}\text { Emotional } \\
\text { channeling } \\
\text { toward venture } \\
\text { development }\end{array}$ & $\begin{array}{l}\text { Founder time } \\
\text { horizon }\end{array}$ \\
\hline $\begin{array}{l}\text { "We just need to be a bit more } \\
\text { dispassionate, step backwards and ask } \\
\text { questions objectively." (BUDGET) } \\
\text { "I fluctuated between sort of a state of } \\
\text { tiredness and complete alertness, but I went } \\
\text { to the gym and l'm feeling renewed." (TECH) }\end{array}$ & $\begin{array}{l}\text { Reducing intensity of own existing } \\
\text { negative emotions such as fear, anger, } \\
\text { frustration, depression; or reducing own } \\
\text { existing positive emotions such as } \\
\text { comfort, pride, and joy regarding aspects } \\
\text { of the venture development. }\end{array}$ & $\begin{array}{l}\text { Tempering } \\
\text { experience of } \\
\text { specific } \\
\text { emotions during } \\
\text { venture } \\
\text { development }\end{array}$ & $\begin{array}{l}\text { Founder time } \\
\text { horizon }\end{array}$ \\
\hline $\begin{array}{l}\text { "We fear that people will be very } \\
\text { aggressive, but in a way we won't be } \\
\text { surprised if it happens...we're preparing } \\
\text { ourselves for that. (INVEST) } \\
\text { "You get very emotionally robust and } \\
\text { tough. That's why normal day-to-day } \\
\text { business doesn't upset you particularly. } \\
\text { It's like water off a duck's back." (DRINK) }\end{array}$ & $\begin{array}{l}\text { Dealing with adverse circumstances that } \\
\text { can cause negative emotions by framing } \\
\text { the situation or reappraising it so that } \\
\text { negative emotions do not even come up. } \\
\text { Not thinking about issues that one knows } \\
\text { in advance will arouse undesirable } \\
\text { emotions. }\end{array}$ & $\begin{array}{l}\text { Emotional } \\
\text { toughening up in } \\
\text { the face of } \\
\text { adversity }\end{array}$ & $\begin{array}{l}\text { Founder time } \\
\text { horizon }\end{array}$ \\
\hline $\begin{array}{l}\text { "As you develop the business, there are } \\
\text { other things that become important, as } \\
\text { well besides the financial opportunity... } \\
\text { You now employ [a large number of] } \\
\text { people, so you have a responsibility for } \\
\text { those people, and you want them to enjoy } \\
\text { themselves, or at least be happy in work." } \\
\text { (BUDGET) }\end{array}$ & $\begin{array}{l}\text { Adding new objects of emotional } \\
\text { attachment that emerge during the } \\
\text { organization building process. Increasing } \\
\text { the variety of founders' emotional desires } \\
\text { associated with building the venture. For } \\
\text { example, adding concern for the welfare of } \\
\text { employees and their families. }\end{array}$ & $\begin{array}{l}\text { Emotional } \\
\text { expanding } \\
\text { during } \\
\text { organization } \\
\text { building }\end{array}$ & $\begin{array}{l}\text { Nature of } \\
\text { founder } \\
\text { rewards }\end{array}$ \\
\hline $\begin{array}{l}\text { "I like working for myself. I remember } \\
\text { working for a big company and I just } \\
\text { didn't like it." (INVEST) } \\
\text { "I wouldn't have been enjoying [working } \\
\text { for a consulting firm]. I don't think } \\
\text { financial salary is a reasonable measure } \\
\text { for me. I'm very happy with what I'm } \\
\text { doing now." (CONSULT) }\end{array}$ & $\begin{array}{l}\text { Emphasizing emotional rewards (e.g., fun) } \\
\text { from business-building more heavily than } \\
\text { economic rewards. This may involve } \\
\text { comparing emotional rewards from } \\
\text { business-building to benefits and/or } \\
\text { drawbacks from a hypothetical alternative } \\
\text { (e.g., employee). }\end{array}$ & $\begin{array}{l}\text { Emphasizing } \\
\text { emotional } \\
\text { benefits of } \\
\text { organization } \\
\text { building }\end{array}$ & $\begin{array}{l}\text { Nature of } \\
\text { founder } \\
\text { rewards }\end{array}$ \\
\hline $\begin{array}{l}\text { "[Building a firm has] the spirit of } \\
\text { adventure and exploration. I never know } \\
\text { what's going to happen, and it's that edgy } \\
\text { feeling of what's going to hit you, which is } \\
\text { fun. Fun is too shallow a word. It's deeper } \\
\text { than that - a sense of flow, of being } \\
\text { alive." (DRINK) }\end{array}$ & $\begin{array}{l}\text { Performing actions during venture building } \\
\text { that elicit emotions such as fun, } \\
\text { excitement, enthusiasm, or joy. These } \\
\text { actions are aligned with the entrepreneur's } \\
\text { personal interest and motivation, and are } \\
\text { often conducted without expectation of } \\
\text { any external reward. }\end{array}$ & $\begin{array}{l}\text { Eliciting } \\
\text { pleasant } \\
\text { emotions in } \\
\text { venture } \\
\text { development }\end{array}$ & $\begin{array}{l}\text { Nature of } \\
\text { founder } \\
\text { rewards }\end{array}$ \\
\hline
\end{tabular}

The fourth step was to identify the firm-relevant outcomes of these diverse ER behaviors. This produced the insight that founders' ER could be associated with the creation of social resources for young firms (not just the founder's emotional well-being), and that differential use of ER 
could be associated with differential resource creation-in other words, with the emergence of heterogeneous social resources. Table 3 illustrates how we derived various forms of resource creation (from founders themselves or from other stakeholders) from their quotes.

\section{Table 3}

Social Resource Creation (RC) Outcomes of Founders' Emotion Regulation Actions

\begin{tabular}{|c|c|c|}
\hline RC Outcome & Definition & Illustrative Quotations ${ }^{3}$ \\
\hline $\begin{array}{l}\text { Resource } \\
\text { creation from } \\
\text { others }\end{array}$ & $\begin{array}{l}\text { Receiving emotional, cognitive, and } \\
\text { material support for the new venture } \\
\text { from other people, or increasing the } \\
\text { likelihood of receiving such support } \\
\text { from others, for example, through } \\
\text { building trust and loyalty with them } \\
\text { (e.g., between the founder and other } \\
\text { TMT members). }\end{array}$ & $\begin{array}{l}\text { "So [the VCs... are] hungry for us." (Founder, DRINK) } \\
\text { "I refused to take no for an answer. Managed to get them back to } \\
\text { the table, and eventually they put the money in." (Founder, TECH) } \\
\text { "Our clients are really paying us money to do stuff." (Founder, } \\
\text { CONSULT) } \\
\text { "As a team it made us very close." (Founder, DRINK) } \\
\text { "We trust each other and we find each other's opinions very } \\
\text { useful." (Founder, CONSULT) }\end{array}$ \\
\hline $\begin{array}{l}\text { Resource } \\
\text { creation from } \\
\text { self: } \\
\text { Discretionary } \\
\text { support }\end{array}$ & $\begin{array}{l}\text { Working hard to ensure successful } \\
\text { venture development: Making } \\
\text { available own emotional resources - } \\
\text { energy and effort - for the venture. } \\
\text { Making available own cognitive } \\
\text { resources (including decision-making) } \\
\text { to resolve important issues regarding } \\
\text { the development of the venture. }\end{array}$ & $\begin{array}{l}\text { "You've got to give it one hundred percent." (Founder, BUDGET) } \\
\text { "I got a new lease of energy...I probably for the next two weeks } \\
\text { worked a hundred hours a week, making just maybe a hundred } \\
\text { phone calls a day, very intensely. We just worked like dogs. I } \\
\text { worked like a dog." (Founder, TECH) } \\
\text { "I'm constantly going, 'Okay, what am I going to do, what am I going to } \\
\text { do, what am I going to do?' You don't sit there and despair. It's } \\
\text { constant-solution, solution, solution." (Founder, DRINK) }\end{array}$ \\
\hline $\begin{array}{l}\text { Resource } \\
\text { creation from } \\
\text { self: } \\
\text { Persistence }\end{array}$ & $\begin{array}{l}\text { Staying with a chosen course of } \\
\text { action regarding the venture } \\
\text { development, even if it is personally } \\
\text { difficult. Staying with the venture } \\
\text { even though there are difficulties. } \\
\text { Extending one's personal time } \\
\text { horizon with the venture. }\end{array}$ & $\begin{array}{l}\text { "You keep pushing on." (Founder, BUDGET) } \\
\text { "You get on with it, really." (Founder, INCUBATE) } \\
\text { "So why would I not, you know, continue the artistry?" (Founder, } \\
\text { DRINK) } \\
\text { "I want to continue." (Founder, INVEST) } \\
\text { "When we started off, it was three to four years, but then of course } \\
\text { reality hit and we realized that it doesn't work that quickly. So I } \\
\text { think it will be, at the end of the day, about a ten-year plan" } \\
\text { (Founder, CONSULT) }\end{array}$ \\
\hline
\end{tabular}

In Table 4 we show the extent to which the founders reported their use of various ER actions. The table shows that Sam (CONSULT) and Kathy (DRINK) clearly stand out as founders who displayed the greatest variety of ER actions, drawing, respectively, on eight and seven (out of eight) categories, some of them quite heavily. Two other founders, Landis (INCUBATE) and Morten (INVEST), stand out at the other end of the spectrum as those who displayed the lowest variety of emotion regulation actions in our study. They enacted only four and two emotion regulation categories, respectively, and they used these very sparsely. The two remaining founders, Jim (BUDGET) and Phil (TECH), enacted six and five ER categories, respectively.

\footnotetext{
3 These quotes are excerpts from coded passages of our data where they could be identified as consequences of founders' ER actions.
} 


\section{Table 4}

Emotion Regulation (ER) Action Categories Used by Founders

\begin{tabular}{|c|c|c|c|c|c|c|}
\hline ER Action Category & BUD-GET & DRINK & CONSULT & INCUBATE & INVEST & TECH \\
\hline \multicolumn{7}{|c|}{ ER Actions Affecting Nature of Founder Rewards } \\
\hline $\begin{array}{l}\text { Emotional expanding during } \\
\text { organization building }\end{array}$ & YES & $\mathrm{MUCH}$ & YES & YES & & \\
\hline $\begin{array}{l}\text { Emphasizing emotional } \\
\text { benefits of organization } \\
\text { building }\end{array}$ & MUCH & YES & MUCH & & YES & YES \\
\hline $\begin{array}{l}\text { Eliciting pleasant emotions in } \\
\text { venture development }\end{array}$ & YES & MUCH & YES & YES & & YES \\
\hline \multicolumn{7}{|c|}{ ER Actions Affecting Founder Time Horizon } \\
\hline $\begin{array}{l}\text { Managing boredom from slow } \\
\text { venture development }\end{array}$ & & & YES & & & \\
\hline $\begin{array}{l}\text { Rekindling of hope regarding } \\
\text { venture prospects }\end{array}$ & YES & YES & YES & & & \\
\hline $\begin{array}{l}\text { Emotional channeling toward } \\
\text { venture development }\end{array}$ & & MUCH & YES & & YES & YES \\
\hline $\begin{array}{l}\text { Tempering experience of } \\
\text { specific emotions during } \\
\text { venture development }\end{array}$ & MUCH & $\mathrm{MUCH}$ & $\mathrm{MUCH}$ & YES & & $\begin{array}{c}\text { MUC } \\
\mathrm{H}\end{array}$ \\
\hline $\begin{array}{l}\text { Emotional toughening up in } \\
\text { the face of adversity }\end{array}$ & YES & $\mathrm{MUCH}$ & YES & YES & YES & YES \\
\hline
\end{tabular}

Table entries:

MUCH - On average more than one quote per interview.

YES - At least one quote (but on average equal to or less than one quote per interview).

Our fifth step was to discover an important moderating condition, which we called self versus other-orientation. In a nutshell, we found that various types of ER action are more likely to lead to beneficial firm-relevant outcomes if they take into account the perspectives and needs of other stakeholders rather than concentrating on those of the founders. We call this the "mode" of emotion regulation. We also noted how various founders shifted from a self- to otheroriented mode of regulation in successive interviews (see Table 5). 


\section{Table 5}

Patterns of Self- Vs. Other Orientation in Emotion Regulation

\begin{tabular}{|c|c|c|c|c|c|}
\hline & First Interview & $\begin{array}{l}\text { Second } \\
\text { Interview }\end{array}$ & $\begin{array}{l}\text { Third } \\
\text { Interview }\end{array}$ & $\begin{array}{l}\text { Fourth } \\
\text { Interview }\end{array}$ & Total \\
\hline DRINK self & 8 & 4 & 3 & 5 & 20 \\
\hline DRINK other & 5 & 6 & 7 & 5 & 23 \\
\hline CONSULT self & 3 & 1 & 1 & 4 & 9 \\
\hline CONSULT other & 3 & $3>$ & 7 & 2 & 15 \\
\hline BUDGET self & 8 & 3 & 3 & 2 & 16 \\
\hline BUDGET other & 2 & $1>$ & 2 & 2 & 7 \\
\hline Subtotal self & 19 & 8 & 7 & 11 & 45 \\
\hline Subtotal other & 10 & 10 & 16 & 9 & 45 \\
\hline INCUBATE self & 1 & 1 & 4 & 2 & 8 \\
\hline INCUBATE other & 2 & 2 & 0 & 0 & 4 \\
\hline TECH self & 2 & 0 & 3 & 8 & 13 \\
\hline TECH other & 0 & 2 & 0 & 1 & 3 \\
\hline INVEST self & 0 & 1 & 0 & 0 & 1 \\
\hline INVEST other & 0 & 0 & 0 & 2 & 2 \\
\hline Subtotal self & 3 & 2 & 7 & 10 & 22 \\
\hline Subtotal other & 2 & 4 & 0 & 5 & 11 \\
\hline
\end{tabular}

Table entries:

Number of reported self-oriented ("self") and other-oriented ("other") ER actions by venture and by interview, focusing on the early business-building phase (first four interviews). For example, " 8 " in the upper left-hand cell of the table denotes that we found eight codes for self-oriented ER actions in the first interview with the DRINK founder.

Note: The arrows in this table depict a possible shift from self- to other-orientation in emotion regulation (for DRINK, CONSULT, and BUDGET) as indicated by a greater ratio of other-oriented ER vs. self-oriented ER; or a possible emphasis on self-orientation in emotion regulation (for INCUBATE, and TECH) as indicated by an increasing ratio of self-oriented ER vs. other-oriented ER.

Finally, we also used interviews with stakeholders other than the founders to triangulate our findings. In Table 6, we describe in aggregated form the levels of social resources created from self (founders) and other stakeholders - for the firms in our study. Juxtaposed with the data we presented earlier on modes (Table 5) and types (Table 2) of ER actions, Table 6 lends support to our argument that founders' ER can be viewed as a partial yet plausible explanation of how heterogeneous resource positions in firms come about. Ventures in which founders used a variety of emotion regulation actions (Table 4) and were other-oriented (Table 5) generally benefited from high levels of social resource creation (Table 6). 


\section{Table 6}

Differential Resource Creation and Emerging Resource Heterogeneity

\begin{tabular}{|c|c|c|}
\hline & der) & rs (Stakeholders) \\
\hline D & $\begin{array}{l}\text { Discretionary support: Founder invests high personal } \\
\text { energy and effort into the venture. } \\
\text { "For Christine the venture was her life, it was her } \\
\text { passion, and she was very motivated, because it was } \\
\text { what she wanted to do." (Barbara, former employee) } \\
\text { Persistence: Founder makes continued efforts, and does } \\
\text { not let up; nor consider any alternative jobs or activities. } \\
\text { "Cash flow was awful. Christine felt the pressure. She re- } \\
\text { mortgaged her house for the business." (Theresa, senior } \\
\text { executive) } \\
\text { High }\end{array}$ & $\begin{array}{l}\text { receives strong personal support from board members and } \\
\text { employees. E.g., whole company participates in devising an } \\
\text { interim range of innovative drink products. } \\
\text { "There was an idea of a new [product]... Everyone wanted to } \\
\text { be involved, everyone wanted to help. I mean everyone, really } \\
\text { everyone, even the nanny who worked for Christine." (Barbara, } \\
\text { former employee) } \\
\text { "Everyone plays an important part in the development of new } \\
\text { products. All get very involved." (Rupert, employee) } \\
\text { High }\end{array}$ \\
\hline $\begin{array}{l}\mathrm{L} \\
\mathrm{T}\end{array}$ & $\begin{array}{l}\text { Discretionary support: Founder constantly searches for } \\
\text { new business opportunities when the core market } \\
\text { slumps. } \\
\text { "Sam will happily work weekends or work on a Sunday or } \\
\text { whatever. He will put the effort in." (Roman, investor) } \\
\text { Persistence: Founder shows continued high enthusiasm } \\
\text { and dedication to the business. } \\
\text { "[We want to] create something of value in terms of, you } \\
\text { know, people feel they belong, and something that, you } \\
\text { know, something that persists." (Matthew, co-founder) } \\
\text { High }\end{array}$ & $\begin{array}{l}\text { Stakeholders give strong discretionary support. For example, } \\
\text { consultants collectively search for new business } \\
\text { opportunities. Stakeholders develop strong adherence and } \\
\text { loyalty to new organization. } \\
\text { "We decided as senior managers to actually go out and get } \\
\text { involved in projects ourselves because we didn't have very } \\
\text { many employees and we needed to bring revenue in." } \\
\text { (Lorenzo, employee) } \\
\text { "Some of the people that I work with amaze me at how quickly } \\
\text { they turn out good quality work." (John, employee) } \\
\text { High }\end{array}$ \\
\hline B & $\begin{array}{l}\text { Discretionary support: Founder kicks into "high gear" } \\
\text { with the acquisition of a hotel chain. } \\
\text { "James is very hands on, very willing to get involved in } \\
\text { anything that needs to be done." (Andrew, lawyer) } \\
\text { "The founders work hard; I'm sure they find it tough with } \\
\text { their families." (Fred, chairman of the board of directors) } \\
\text { Persistence: Founder displays continuous, steady effort. } \\
\text { "[James] is very committed." (Ruth, HR director) } \\
\text { High }\end{array}$ & $\begin{array}{l}\text { Stakeholders give strong discretionary support (e.g., } \\
\text { managers volunteer to get personally involved with operation } \\
\text { of new hotels). Very low turnover among employees. } \\
\text { "We've got a lot of very good employees, and we realize how } \\
\text { hard they work." (Ruth, HR director) } \\
\text { "I personally just wanted to try and help wherever I could with } \\
\text { that implementation, and you know, offer my services." (Sevin, } \\
\text { general manager) } \\
\text { High }\end{array}$ \\
\hline $\begin{array}{l}\mathrm{T} \\
\mathrm{E} \\
\mathrm{C} \\
\mathrm{H}\end{array}$ & $\begin{array}{l}\text { Discretionary support: Founder invests himself } \\
\text { thoroughly in the business, but in a way that eventually } \\
\text { alienates others. } \\
\text { "His drive was a key part of moving the company forward } \\
\text { from the beginning." (Daniel, BoD chairman) } \\
\text { Persistence: Founder holds on to his "baby" until fired. } \\
\text { "When he had to hand over more operational } \\
\text { responsibilities [to the newly hired CEO], he didn't like } \\
\text { that." (Kevin, co-founder) } \\
\text { "I think that because it was his baby, he could not let go. It } \\
\text { must just have torn his heart." (Stanislav, employee) } \\
\text { High (but with negative consequences for the } \\
\text { company) }\end{array}$ & $\begin{array}{l}\text { With ongoing problems, stakeholder support weakens. } \\
\text { Emerging rifts at board level, bitter personal disputes among } \\
\text { TMT members. Dismissal of CEO, personnel cuts. } \\
\text { "I work pretty serious hours and really try to make this work." } \\
\text { (Stanislav, employee) } \\
\text { "I'm an incredibly emotional and passionate person, and so is } \\
\text { Phil. We had fairly heated discussions in which I was told that } \\
\text { I was wrong and it wasn't going to happen that way." } \\
\text { (Stanislav, employee) } \\
\text { "The trust was broken between board members and Phil." } \\
\text { (Kevin, co-founder) } \\
\text { First High, Then Low }\end{array}$ \\
\hline
\end{tabular}




\begin{tabular}{|c|c|c|}
\hline & Creation of Social Resources from Self (Founder) & Creation of Social Resources from Others (Stakeholders) \\
\hline $\begin{array}{l}\text { I } \\
\text { N } \\
\text { C } \\
\text { U } \\
\text { B } \\
\text { A } \\
\text { T } \\
\text { E }\end{array}$ & $\begin{array}{l}\text { Discretionary support: When things do not go as } \\
\text { planned, founder disconnects from the business. } \\
\text { "Every day was a battle, because it was a very big } \\
\text { challenge. That brought him a lot of worries, which in a } \\
\text { way I would say even affected his health:" (Susan, wife) } \\
\text { "I think being married with kids and having, you know, a } \\
\text { certain lifestyle expectation that Landis wasn't able to } \\
\text { sacrifice." (Kurtis, co-founder) } \\
\text { Persistence: Partly under pressure from his wife, returns } \\
\text { to previous job. } \\
\text { "I think for him to be in a more corporate environment, } \\
\text { bringing a sort of sense of security, is nice. He doesn't } \\
\text { worry as much." (Susan, wife) } \\
\text { "Landis went back to consulting." (Kurtis, co-founder) } \\
\text { Low }\end{array}$ & $\begin{array}{l}\text { Weak support from stakeholders, except co-founders, whose } \\
\text { enthusiasm for the venture fades over time. Lack of external } \\
\text { finance, low sales. Hidden tensions within TMT. } \\
\text { "We had the first major falling out at that point because } \\
\text { Landis negotiated in a non-partner way." (Kurtis, co-founder) } \\
\text { "The growth was disappointing and so we did some things, } \\
\text { you know, kicked some people and we changed the way } \\
\text { some people were motivated." (Kurtis, co-founder) } \\
\text { "[The employees] were like workers in a factory." (Susan, } \\
\text { wife) }\end{array}$ \\
\hline $\begin{array}{l}\text { I } \\
\text { N } \\
\text { V } \\
\text { E } \\
S \\
T\end{array}$ & $\begin{array}{l}\text { Discretionary support: Founder displays a professional } \\
\text { attitude, expends measured (not extraordinary) effort. } \\
\text { "Michael likes to do a good job." (Alex, member of the } \\
\text { board of directors) } \\
\text { Persistence: Founder decides to stay with venture, but } \\
\text { partly motivated by lack of alternatives. } \\
\text { "When the business got into difficulties, [Michael] still } \\
\text { stood by it." (Alex, member of the board of directors) } \\
\text { Medium }\end{array}$ & $\begin{array}{l}\text { Political in-fighting, conflicts about strategy, pursuit of } \\
\text { economic self-interest. TMT members mainly motivated by } \\
\text { financial stake in business. } \\
\text { "[The TMT members] were concerned about internal politics } \\
\text { as much as they were concerned about doing business...they } \\
\text { were all concerned to protect their interest." (Alex, BoD } \\
\text { member) } \\
\text { "Some became very bitter and angry about what was } \\
\text { happening." (Nelson, former senior partner) } \\
\text { Medium }\end{array}$ \\
\hline
\end{tabular}

\section{Findings on Emotion Regulation and Resource Creation}

The founders we studied differed both in terms of the types of ER they enacted and how they performed them. Our key findings regarding ER cluster around three distinct themes related to organization-building: 1) the founder's temporal perspective (short-term versus long-term); 2) the nature of founder benefits (economic versus emotional rewards), and 3) the target of founder attention (self versus others). Our analysis revealed, moreover, that these individual-level behaviors were often (though not always) associated with important firm-level outcomes, which we conceptualize as creation of social resources for the venture. ${ }^{4}$

\footnotetext{
${ }^{4}$ In the presentation of our findings, we focus on those data that helped us build our concepts, and suggest a causal link between the founder's ER and resource creation for the venture, because this link has not yet been shown empirically in the literature, and has been under-explored theoretically. For easier interpretation, code indicating emotion regulation is shown in bold.
} 


\title{
ER Actions Relating to Founder's Temporal Perspective
}

As we described in the Methods section, we identified eight ER action categories from our data, which are shown in Table 2. Five of these "first-order concept" categories - which we call "reducing boredom," "eliciting hope," "emotional toughening up," "emotional channeling," and "tempering of extreme emotions" - cluster around the "second-order theme" related to the challenge of simultaneously managing short - and long-term requirements for the venture. Founders needed to focus on current, short-term business tasks but at the same time keep sight of their future, long-term business-building objectives. Sam, the founder of CONSULT, described his long-term objectives: "I want something that'll last. It'll probably be bought up, it might change its name, it might do all sorts of things, but to have something that could survive without me being there is quite important." But short-term considerations often risk undermining their longterm perspective, as Matthew, the founder of INVEST, shared with us: "From time to time, we [cofounders] talk to each other and we say, what do we do if this thing doesn't work? And you know, there's all sorts of ideas."

The challenge of handling both short- and long-term considerations is perhaps most salient during periods of stagnation or decline in business performance, or just before a highly uncertain potential growth opportunity. At these points, founders have most need to ensure the short-term survival of their business, and can feel torn between the urge to abandon ship and the struggle to keep it afloat. Christine, the founder of DRINK, described her challenge as follows:

\begin{abstract}
“The products are just flying. We've got these rewards, and the importers are really starting to listen. It's just starting to get a head of steam in it. I'm spread very thinly. Emotionally, how do I cope? That's a really good question. I live in hope, I know how to fight fires and I know how to get things in very fast.... Yes, I live in hope, but it's getting really very dicey now personally. I mean, I'm just pulling it back, but it's just too far. It's gone way too far on the personal finance side. I don't have a credit card I can use. All of that's gone.” (Founder DRINK)
\end{abstract}

The ER actions mentioned in this section not only helped the founders regulate their own emotions during business-building, but also influenced their temporal perspectives (e.g., shortterm versus long-term, present versus future). Due to space considerations, we describe only one type of ER action (namely, "managing boredom from slow venture development") in depth in the Appendix to convey the richness of our data and summarize the other four ER types of behavior in Table 2.

Firm-level benefits: Resource creation from self (founder's persistence). Our data show that the type of ER actions that influence founders' temporal perspective helped founders persevere with their venture development, especially when they faced difficulties. For instance, when we asked James, the founder of BUDGET, how he coped with stress and the prospect of failure and total loss of his investment in the venture, he explained:

"Of course I worry about it, of course I think about it and of course I'm impatient because I want it to move forward much more quickly. But at the same time I've got to be realistic about it, because otherwise I would just end up being totally stressed all the time. I find exercise very helpful. I go to the gym. If there is any pent-up frustration, if I've had a bad day, because you live by the day, then that's a good way of getting rid of it." (Founder BUDGET)

Reducing negative emotions through physical exercise helped this founder get his mind off depressing concerns about unsatisfactory progress in venture development. This type of ER action

16 - IESE Business School-University of Navarra 
renewed the founder's patience and helped him refocus on his longer-term business building goals, beyond the specific daily challenges. Ruth, the HR director of BUDGET, confirmed in a separate interview that James typically felt "quite a bit of impatience." But she also noted how he acted to reduce his negative emotions and avoid them from spilling over onto other employees in a harmful way: "The founders contain tensions between the three of them and work out their problems. They have their argument and then they come out with a solution, rather than it be shared amongst other people." Fred, BUDGET's chairman of the board, also noted: "Well, obviously the emotions, they usually keep them pretty well in check, certainly when I'm there." And Andrew, BUDGET's lawyer , described James as follows:

"In emotional highs and lows, he is this very calm, constant person. I've dealt with other people in business who clearly do veer from one extreme to the other, completely the opposite of how James deals with things. The occasional moments that he looks as if he's under pressure, he still maintains his basic calm. He ticks away. I don't know what he does in private, if he lets it out some way. But when he's facing the world, he constantly keeps his calm." (Lawyer BUDGET)

In a related vein, some founders stayed focused on their long-term objectives despite alternative employment opportunities, and/or they extended their personal time horizon with the venture (i.e., they prolonged the length of time they had originally planned to dedicate fully to the venture until their planned exit from the business). We call this social resource "founder persistence." Founder persistence is valuable to nascent firms, which are vulnerable and dependent on the stewardship of a few dedicated individuals.

Table 3 displays more supporting evidence for this concept. Recall that the quotes shown in the table are interview excerpts that were outcomes of founders' ER actions. For example, Sam of CONSULT explains his and his senior executives' persistence by pointing out the emotional rewards they derived from developing a firm: "I really enjoy [developing a company]. This is the thing I think that keeps us all going." As this quote suggests, the persistence of the founder ("keeps us... going") is causally linked to his ER behavior (eliciting pleasurable emotions, such as joy, through venture development).

\section{ER Actions Relating to the Nature of Founder Benefits}

Returning to the types of ER action founders enacted, we inferred that the remaining three of the eight first-order action categories we identified - "emotional expanding," "emphasizing emotional benefits," and "eliciting pleasant emotions" - refer to the nature of founders' rewards; more specifically how founders can complement their potential economic rewards with ER behaviors that bring them additional emotional rewards. In the literature this is referred to as "psychic income" (e.g., Gimeno et al., 1997) or subsumed in non-wealth-related rewards (see Amit et al., 2000). Consider how Steve, the founder of CONSULT, commented on what it was like to build and operate a new firm:

"I absolutely love it. I enjoy running a company, I enjoy making the decisions. I enjoy having the opportunity to be entrepreneurial when I want to be entrepreneurial, so if I have a good idea or my business partner has a good idea, we can sit down, we can have a coffee and in ten minutes we can decide we're going to spend some money and try something else. In a big company, that would take a year. So I love that. I like the variety. I like being operations one day, I like being sales the next, I like doing some marketing the following day. I like to be able to choose my own hours." (Founder CONSULT) 
Not every founder we studied was able (or willing) to draw emotional rewards from venturing. For example, the main reason why Landis, the founder of INCUBATE, was engaged in business-building was the prospect of becoming personally wealthy. As he explained to us, "If you multiply probability by best outcome, there's more of a chance to really make it big being an entrepreneur."

Balancing the goal of creating economic wealth with the socio-emotional payoffs from firmbuilding may not always be easy, for example, when things are not going well and founders perceive that an increase in business performance might only be possible at the cost of prolonged personal hardship (e.g., long hours spent at work). The reverse could also happen, that is, an increase in personal well-being (e.g., taking more time off work) could negatively affect business performance. ER behaviors such as "emotional expanding," "emphasizing emotional benefits," and "eliciting pleasant emotions" not only help the founders regulate their own emotions during business-building, but they also influence their subjective balance between emotional and economic rewards. James, the founder of BUDGET, a former venture capitalist and an exceptionally strong analytical thinker, described his own psychological reward-related balance as follows:

“Let's be honest. If I was going to make no money out of it, I wouldn't do it. One of the prime motivations in setting up a business to me is to make enough money that you end up financially secure. I'd love to repeat this exercise, because I think it's a fantastically exciting performance. But the other driver is actually being able to create something, being able to say, see that hotel there? That's our hotel. We built it, we run it. This is our business." (Founder BUDGET)

To convey a fine-grained understanding of our data in light of space considerations, we describe "emotional expanding" in greater depth in the Appendix. ("Emphasizing emotional benefits" and "eliciting pleasant emotions" are summarized in Table 2.)

Firm-level benefits: Resource creation from self (founder discretionary support). Thanks to ER actions influencing the nature of founders' perceived rewards, founders provide their firms with strong support and efforts that facilitate venture development. This can involve making their own psychological resources - e.g., energy - available for the venture (e.g. "I gave the venture development one hundred per cent of my energy"). It can include devoting their cognitive resources - e.g., decision-making, creativity, and sustained attention - to addressing the challenges of developing the firm (e.g., "I left [my former employer] and focused on building a business"). We call these social resources provided by founders "discretionary support," to convey that founders make additional efforts for the venture over and above what they would normally have done. For example, Sam, the founder of CONSULT, found making sales calls to prospective clients exciting. This emotional excitement allowed him to perform this vital activity with dedication:

"For me sales were completely new. It gave me the adrenalin buzz that I got originally from starting the company, having never done this... Once you get up, you have to get a completely different mindset on, just saying right, I'm going to make twelve sales calls this morning and that's it... I have three cups of coffee, wait until I'm sitting there buzzing with caffeine, and then I just go for it. So that was what was getting me out of bed...I knew I was the best person to give it a go." (Founder CONSULT)

Sam received emotional rewards (excitement) from engaging in sales activity, which should also help building business for the young firm. Randy, an investor in CONSULT, confirmed this in a separate interview: "Sam enjoys working for himself. He gets a lot of satisfaction from it." 
The founder's joy helped the young firm because this emotion increased the founder's motivation and effort level, which are important social resources for a new firm. (See Table 3 for more evidence of founder's discretionary support from our data.)

\section{ER Actions Relating to Target of Founder Attention}

How do founders at any given point in time balance their own needs, perceptions, preferences, and desires with those of other people involved in the firm-building process? Our data suggest that some founders enacted more other-oriented ER over time. This means that in regulating their own emotions they paid increasing attention to the needs, goals, and feelings of other people in conjunction with their own. In performing their own emotion regulation, they integrated others' needs and feelings (Agrawal, Menon, and Aaker, 2007). Listen, for example, to how Kathy described her way of dealing with a cash crisis:

"It's very, very tough [to deal with cash crises]. It's like chicken. You don't blink. You keep driving. And it's very tempting not to, and if I don't, everybody else will kind of sit down and get depressed. You just drive, drive, drive, drive very hard and push more to continue to get the business to develop. Personally it's quite grueling." (Founder, DRINK)

Kathy dealt with the extreme shortage of cash and the impending bankruptcy of her young business by mobilizing all her energy ("drive, drive, drive") and professional effort in order to deal with the business problem in a constructive way ("continue to get the business to develop”). She did not allow herself to be paralyzed by anxiety or depression. Her stamina, discipline, and will-power could be considered remarkable in and of themselves. But what is noteworthy here is that in dealing with her own intense emotions (depression, pain, fear) caused by the difficult economic situation, Kathy anticipated other people's emotions ("everyone else... will get depressed"). Kathy's ER actions ensured, among other things, that others would not feel depressed by the economic crisis, and that the young firm would acquire adequate economic resources to ensure the well-being of its members.

We also coded ER actions as "other-oriented" when the founders told us they had listened to other people's feedback as part of their own ER response. For example, when CONSULT experienced a period of slow growth, the founder of the company, Sam, listened carefully to his investors, which helped him temper his own frustration.

"I think [the slow growth] is a bit frustrating. But then I also have a reality check. I do talk to investors, for example, and say things like how do you think we're doing? Most of them say you know, [Sam,] I know you're a bit disappointed with how it's going, but I'm glad you're still there, and boy, you should see some of my other investments-and that makes me feel good again. So I just remind myself that we are all ambitious people, we want this thing to grow really quickly, but we've got to be sensible about it. There's no point forcing growth for growth's sake." (Founder, CONSULT)

As a result of his proactive advice seeking and integrating other people's perspectives in his ER, Sam reduced his frustration and disappointment. This helped him increase his patience with the firm-building process, which represented an important benefit for the young firm compared with ventures in which discouraged or frustrated founders lost interest, got distracted by other things, or reduced their contribution to the firm in terms of time and effort. 
These important firm-level benefits become even more salient when we contrast Sam's otheroriented ER behavior with that of Phil, the founder of TECH, who used largely self-oriented ER actions to reduce his own worry and unhappiness about being asked to step down as CEO of the firm he had founded (which he referred to as "my baby"). That is, Phil mainly took into account only his own goals and desires in regulating his emotions. For example, he lobbied intensely against the search for a new CE0, because this threatened his own personal career ambitions within the company he had helped create, even though attracting a new competent leader would benefit the young firm as a whole. His lobbying efforts eventually led to the creation of a dual CEO position, a compromise that would prove dysfunctional for TECH. The mounting tensions between the "CO-CEOs" resulted in Phil writing e-mails in which he blamed the new CEO for not generating sales. Writing such e-mails allowed Phil to convey information and reduce his anger as he vented it. This mode of self-oriented ER action met his self-oriented need (i.e., feeling better personally), but at the firm level aggravated the tensions among board members, which culminated in Phil's dismissal. As Phil recounted, "I was fired when I sent this email. And, in retrospect, I probably shouldn't have sent it."

Table 5 summarizes our analysis of founders' self - versus other-oriented ER behaviors and shows temporal trends in the use of self - and other-oriented ER. This table shows that the founders of DRINK and CONSULT, in particular, evolved to other-orientation mode in ER relatively early in the development of their firms. The downward sloping arrows (from "self" to "other") in Table 2 for the two firms between the first and second interview show these early trends. As for BUDGET, although it seems that founders' self-oriented ER actions dominated across all four interviews, the proportion of self- versus other-oriented ER actions declined consistently (from 8:2 to 3:1 to 3:2 to 2:2). More informative perhaps, the qualitative evidence suggests that the founder of BUDGET underwent a process of shifting from self- to other-orientation, triggered by the acquisition of a number of hotels with a large number of staff. This exogenous shock could have easily derailed the fledging young firm. The founder's pattern of behaviors (not just his ER actions) shows that at this very juncture he made a transition toward other-orientation. For example, together with his business partner, he began to meet regularly with the general managers of the acquired hotels, and showed concern for their personal well-being, not just focusing on the firm's business performance.

Within INCUBATE and TECH, we found that the self-oriented ER mode of the founders' actions dominated other-oriented ER, particularly in the later stages of firm development, when the founders were confronted with continued business-building challenges. We depict this focus on self-orientation with an upward pointing arrow. (Note that this arrow does not suggest a transition from other- to self-oriented ER, because the qualitative evidence in these cases does not allow us to conclude that the founders of INCUBATE and TECH were originally other-oriented.) As for INVEST, there were simply too few discernible ER actions to infer a dynamic pattern.

Firm-level benefits of other-oriented ER: Creation of social resources. Interestingly, we found that founders' ER of self could influence others to support the venture. Listen to how Christine, the founder of DRINK, describes how she elicited pleasant emotions in herself by exploring future possibilities for her firm and including others in this process ("other-oriented" ER action).

"I love exploring the new, sharing the new. The building of the concept and then seeing it come alive is really, really fascinating. I see something and for me it's so clear. I can see the contours. I see the shape, everything it could be. It's like everyone else is looking at the same piece of art and they think, you do? We don't see that. Then the form starts to become clear. It doesn't have to be the form as I originally saw it, and often it isn't, but other people come around and get huge satisfaction out of it." (Founder DRINK) 
Christine anticipated that "other people" could not see what she initially saw. They might have harbored serious doubts. The fact that Christine displayed fascination about the concept and sharing her excitement with others likely influenced others to "come around" and share her vision, as she reflected. Jordi, an industry expert whom Christine approached for advice, confirmed in a separate interview to us that "people are cautious about taking on people they don't know about. Now that's where the passion of someone like Christine is very useful... So I helped her." And Theresa, a senior executive of DRINK also validated that, "Christine has a quality that enables her to see not just the next step or the step after that, but ten steps forward ...We were just drawn in to her idea and her vision and her energy to execute it."

Our data suggest that founders' ER actions that are other-oriented are frequently associated with the creation of social resources involving others, for example, the willingness-to-support of investors, or the commitment of new employees (see Table 3). Within DRINK, CONSULT and BUDGET, we could not find a single self-oriented ER action associated with resource creation from others. In ventures where the founders used predominantly self-oriented ER actions (INCUBATE, INVEST and TECH), we found very little evidence of resource creation from others. Instead, we found much evidence to the contrary; for example, stakeholder support declined significantly as a result of the founder's self-oriented ER actions, with sometimes devastating consequences for the young firm's chances of survival.

\section{Toward an Emerging Model of Emotion Regulation and Resource Creation}

Our data allow us to establish empirically the association between a variety of founders' ER actions and creation of social resources (both from founders and other firm stakeholders) for new firms. To the best of our knowledge, this association has not been shown empirically before with a high level of granularity, that is, by identifying (a) the various types of ER, and (b) how they are used (i.e. modes: self- versus other-oriented).

Figure 1 summarizes graphically an empirically-grounded model linking founders' ER action types, their ER action mode (i.e., the degree of other- or self-orientation), and the creation of social resources for their ventures.

\section{Figure 1}

How Founders' Emotion Regulation Affects Resource Heterogeneity

Founder ER Action Types

(a) ER actions relating to founder temporal perspective: Reducing boredom, eliciting hope, emotional toughening up emotional channeling, tempering of extreme emotions

(b) ER actions relating to nature of founder rewards: Emotional expanding, emphasizing emotional benefits, eliciting pleasant emotions
Founder ER Action Mode

Resource Creation For Venture

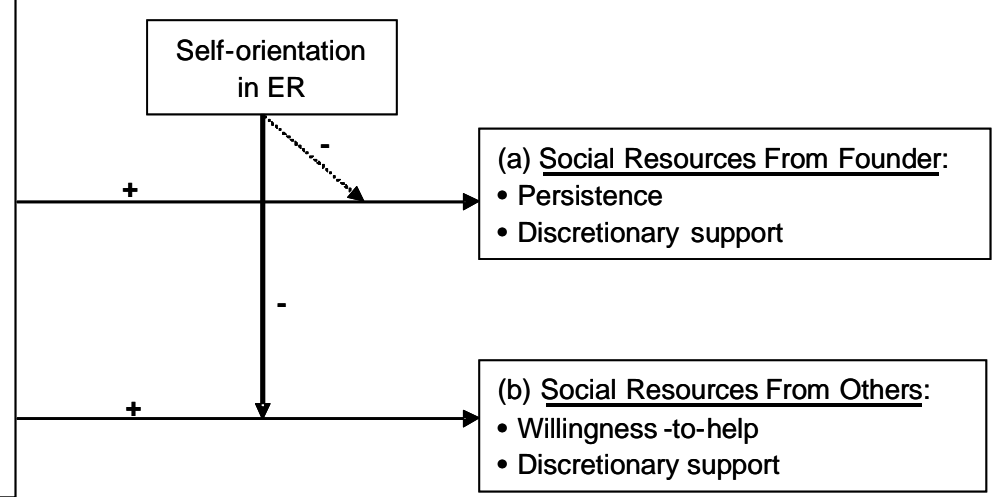


The model depicted in Figure 1 shows which ER actions performed by founders can create social resources for their ventures. We can capture the main implications of our predictive model in the following propositions:

Proposition 1: Founders' ER actions relating to their temporal perspective (i.e., managing boredom, rekindling of hope, emotional channeling, tempering specific emotions, and emotional toughening up) increase founders' persistence with their ventures.

Proposition 2: Founders' ER actions relating to the nature of their rewards (i.e., emotional expanding, emphasizing emotional benefits, and eliciting pleasant emotions) increase the discretionary support founders give their ventures.

Proposition 3: Founders' ER actions are positively associated with resource creation involving stakeholders other than the founders themselves.

These positive relationships between ER action types and relevant firm-level outcomes are moderated by the founders' "self- or other-orientation" in ER (i.e., by the ER action mode adopted). Specifically, we suggest that self-orientation has a negative moderating impact. Phil, the founder of TECH, for example, was attuned to his own emotions, which he regulated using a variety of ER actions (see Table 4). But Phil performed these behaviors in a largely selforiented fashion, often ignoring the perspectives of other stakeholders. The result was destruction rather than creation of social resources: Phil lost the support of his senior management team and other important stakeholders, such as members of the board of directors. In fact, he lost the company he founded, as he was ultimately dismissed by the board after fighting a long and hard battle to keep his position; the firm's assets were eventually sold off. This suggests a negative moderating effect of self-orientation on the relationship between ER actions and resource creation from others (see Figure 1).

Proposition 4: The degree of self-versus other-orientation in founders' ER affects the creation of social resources in ventures. The higher the degree of self-orientation, the weaker the positive effect of founders' ER on the creation of social resources involving other stakeholders.

The example of Phil and TECH also highlights another noteworthy nuance to our model, in that the founder's persistence may not always represent a benefit for the firm. As in the case of $\mathrm{TECH}$, if persistence is the result of a founder's predominantly self-oriented ER, such persistence might harm the firm's development. Persistence could, for example, prevent the young firm from evolving beyond a self-oriented founder who has lost the support of other firm members. Founders' persistence could be dysfunctional for the firm. In our model, we therefore depict a negative moderating effect of founders' self-oriented ER on the positive relationship between ER and resource creation from self (persistence). Although the hypothesized moderating effect would not reduce the strength of the founder's persistence, it would affect its usefulness for the firm, more precisely its contribution to the young firm's development. The dotted line in Figure 1 denotes this effect. It is dotted 1) because it relates specifically to founder persistence as an outcome, and 2) because it refers to the usefulness of the founder's persistence, and not to its strength.

Proposition 5: The degree of self-versus other-orientation in founders' ER affects the creation of social resources in ventures. The higher the degree of self-orientation, the weaker the positive effect of founders' ER on useful founder persistence for the venture. 
Overall, our theory on founders' ER provides an explanation of resource heterogeneity at the firm level. Our findings suggest some of the boundary conditions related to the benefits of founders' ER. Our model does not suggest that that more ER by the founder (in a quantitative sense) is necessarily better for the venture. Drawing on a broad repertoire of actions to address specific contextual conditions is more adaptive than frequently performing a narrow set of selforiented ER actions.

\section{Discussion and Conclusion}

A core tenet of resource-based strategy is that firms' resources are heterogeneous (Amit and Schoemaker, 1993; Barney, 1991, 1997; Peteraf, 1993; Peteraf and Barney, 2003). But what are the origins of resource heterogeneity? Where do they come from? What are the contributing factors and mechanisms that explain its emergence? In this study, we start to reveal the microfoundations of firms' resource-based strategy, focusing on founders' affect-related behaviors and how they help create social resources for nascent firms. Our findings yield fine-grained insights into the psychological processes that shape emerging differences in the repertoires of social resources accessed by young firms. These findings suggest that the emergence of resource heterogeneity can have "affective roots," that is, it can be explained by the ways in which founders regulate their affective states during the venture-building process. Obviously, we do not suggest that ER is the only mechanism that generates heterogeneous resources, but it is one enabler that has been largely overlooked by strategy and entrepreneurship scholars to date.

\section{Why Does Emotion Regulation Help Create Resources for Ventures?}

We found that founders' ER addresses three themes that characterize the early startup phase: founders' temporal perspective, the nature of rewards, and the target of attention. We could interpret these themes as tensions, which refer to the subjective perception that focusing on one particular goal (or need) seems incompatible with the pursuit of another (Lewis, 2000; Lüscher and Lewis, 2008).

The first tension, short-term versus long-term perspective, involves a dynamic trade-off across time horizons. Here, founders psychologically integrate the need to focus on current, short-term business challenges with the imperative to not lose sight of the future. This tension is addressed, amongst other things, by ER actions that help founders deal with their current emotional stress while simultaneously taking a long-term perspective: managing boredom from slow venture development, which helps the founder stay focused on the present business development needs of the venture despite recognizing that this focus may not elicit pleasant emotions; rekindling of hope regarding venture prospects, which reinforces the founder's positive belief in the future potential of the business; and emotional channeling, tempering of extreme emotions, and emotional toughening up, which protect the founder from becoming too discouraged by adverse business conditions that may appear overwhelming at first sight.

By enacting any of these ER behaviors, founders reconcile seemingly opposing temporal perspectives. ER related to temporal perspectives can influence the amount of attention founders pay to present and future business development activities and help them resolve the difficult trade-off between a short- and long-term focus (e.g., eliciting subjective hope about a better future gives the founder renewed energy to persevere and stay committed to the venture 
during difficult times). They can thus motivate founders in terms of willingness to bear uncertainty (McMullen and Shepherd, 2006) and incentivize them for a long-term horizon.

These founder ER behaviors could also potentially influence the creation of social resources involving other stakeholders. A future-oriented, long-term vision represents a universally accepted positive leadership prototype (Dorfman et al., 2004; Javidan et al., 2006). Stakeholders' positive feelings toward entrepreneurial leaders will increase the amount of motivation and extra effort they expend in helping their leaders achieve organizational goals (Luque et al., 2008). Thus, founders' ER could lead to greater alignment between their own and stakeholders' incentives (Jensen and Meckling, 1976; Gottschalg and Zollo, 2007).

The second tension, economic versus emotional rewards, takes into account how founders psychologically complement the goal of creating economic wealth with the need for socioemotional payoffs (which Gimeno et al., 1997, denote as "psychic income") from the venturebuilding experience. This inner integration appears most needed when things are not going well for the venture and an increase in business performance appears obtainable only at the cost of increased personal hardship or emotional stress. The trade-off can be addressed by, among other things, the types of ER action that create increased emotional rewards for founders: emotional expanding, through which founders add new objects of emotional attachment related to their venture-building activity; emphasizing emotional benefits, which involves founders putting more weight on emotional rewards, especially in comparison with those they gained from previous professional experiences; and eliciting pleasant emotions in venture building, when the founder deliberately engages in business-building activities that are emotionally rewarding (eliciting fun, joy, excitement).

By enacting these types of ER action, founders fuel their intrinsic motivation, creating new incentives for themselves (Deci, 1975; Gottschalg and Zollo, 2007). These additional incentives can lead to the creation of valuable social resources for the venture. For example, a stronger subjective emphasis on emotional rewards helps founders generate additional energy and discretionary effort to support their ventures during periods of uncertainty, adversity, or low performance (Gimeno et al., 1997).

In addition, founders' ER behaviors can also lead to enhanced social resources involving other stakeholders. Recent research has found that leaders' emphasis on economic values versus stakeholders' values can influence employees' extra effort, which relates to firm performance (Luque et al., 2008). Leaders who emphasize predominantly economic values, such as profit maximization and shareholder supremacy, tend to elicit negative emotions among their employees, who perceive their leaders as autocratic, instrumental, and emotionally insensitive (Ghoshal, 2005; Yulk, 2006). In contrast, leaders who emphasize "soft" benefits, such as emotional rewards, can elicit positive emotions that energize extra motivation and effort among followers (Dorfman et al., 2004; House et al., 2004). Thus, founders' ER could lead to greater alignment between themselves and other stakeholders (Jensen and Meckling, 1976; Gottschalg and Zollo, 2007) - not in terms of extrinsic (monetary) rewards, but in terms of intrinsic (psychic) rewards.

The third tension, self- versus other-orientation, takes into account how founders psychologically integrate their personal needs, preferences, and desires with those of other people involved in the firm-building process. By enacting other-oriented ER, founders not only regulate their own emotions, but also temper their own agency - which could be perceived by others as egocentric - and thus consciously address the delicate balancing act between self and 
others' needs. Addressing others' needs strengthens other stakeholders' incentives to support the venture, and increases the odds of obtaining resources from them.

By enacting other-orientation, founders show benevolence, which is a key antecedent to trustbuilding (Mayer, Davis, and Schoorman, 1995). Benevolence is the extent to which a person is perceived to want to do good for others, aside from any egocentric motives. Whitener and colleagues (1998) argued that actions by managers that show consideration and sensitivity for other people' needs and interests, and refraining from exploiting others for the benefits of one's own interests, are part of trustworthy behavior. And enhanced trust increases the odds of cooperative behaviors (Dirks and Ferrin, 2001).

\section{Founders' Emotion Regulation and Resource-based Theory}

Because resource-based theory (RBT) takes resource heterogeneity as a starting point in its chain of logic aimed at explaining differential intra-industry firm performance, and our model shows resource heterogeneity as an output, our research provides an opportunity for embedding our proposed model of founders' ER actions (see Figure 1) in a broader resource-based framework. Our affect-based theory on the origins of resource heterogeneity could form the "front-end" of a more developed RBT, and advance it by mitigating some of the key concerns that have been leveled against it (e.g., Priem and Butler, 2001). To accomplish this, we build on and extend the resource-based framework developed by Peteraf and Barney (2003). Figure 2 shows a tentative integration of our model within that framework.

\section{Figure 2}

Emotional Regulation And Resource-based Theory (Logical Chain)

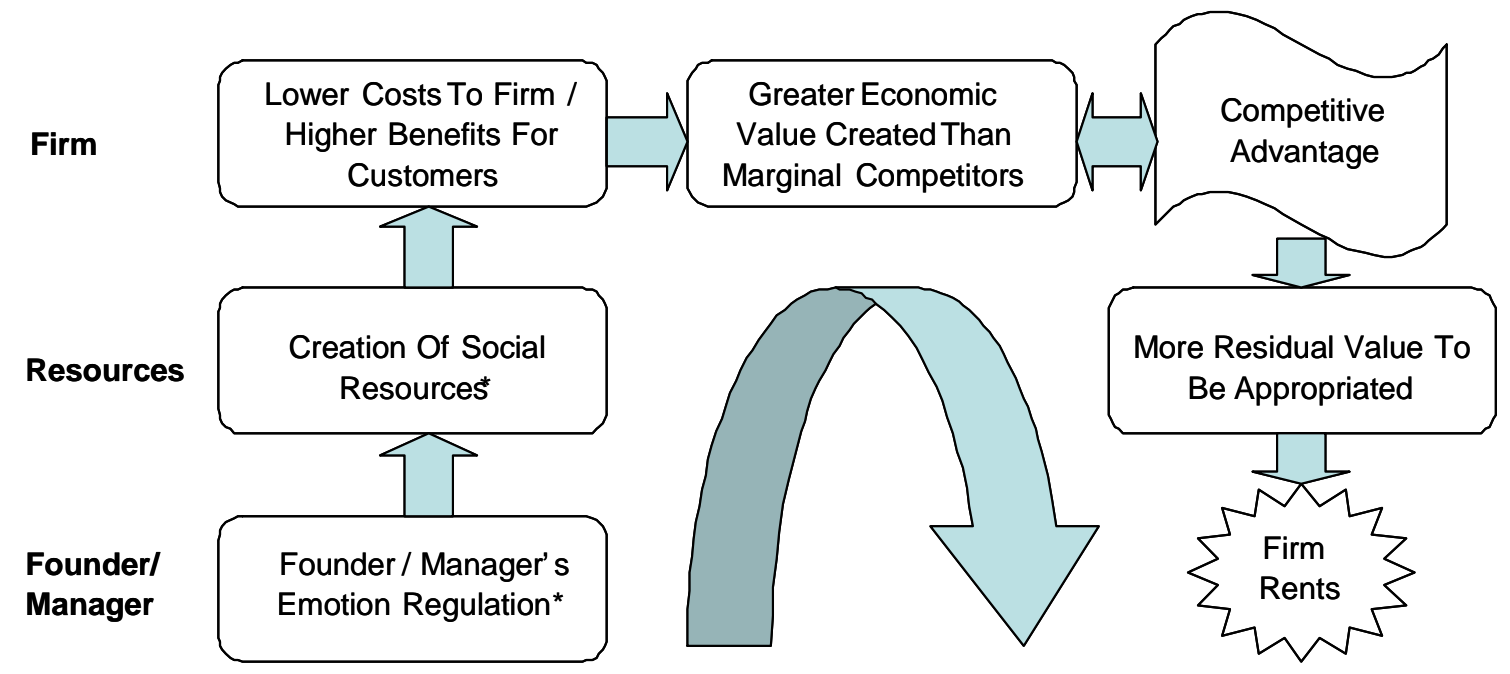

Source: Adapted from Figure 3 in Peteraf and Barney (2003).

* Denotes novel elements

Peteraf and Barney (2003, p. 314) defined economic value as "the difference between the perceived benefits gained by the purchasers of a good and the economic cost to the enterprise," and competitive advantage as "creating more economic value than the marginal (breakeven) competitor" in the firm's product market. Firms that enjoy a competitive advantage can 
potentially appropriate more value than their competitors and earn economic rents. Resourcebased theory assumes that the firm's ability to generate lower economic costs or increase perceived customer benefits is a function of the firm's "superior critical resources" (Peteraf and Barney, 2003, p. 314), which are assumed to be heterogeneously distributed across firms.

We propose to complement RBT with the process of differential resource creation in the early days of a firm. Social resources that are endogenously created during organization-building can affect the costs and perceived benefits of the firm's offerings (e.g., the extra effort put in by the company's founders or employees to serve customers could yield improvements in perceived service quality). Our theory thus endogenizes the mechanisms that render resources valuable to a firm and provide a basis for its competitive advantage. According to Barney (1997), that advantage could be sustainable if the resources at its origin are valuable, rare, and costly to imitate. The cost of imitation hinges on resource properties such as causal ambiguity and social complexity (Barney, 1997, pp. 154-158), which social resources can possess. Causal ambiguity, for example, refers to a lack of understanding of the links in the causal chain that extends from the ways social resources are created through founders' ER actions to their effects on competitive advantage.

Indeed, our data suggest that founders may be constrained by their belief systems about the usefulness of emotions and ER. Consider Landis, the founder of INCUBATE, who has an engaging, lively personality (which he shows in personal interactions), yet maintains a strictly task focus-cognitive perspective on business. According to his belief system, emotions are not helpful for business effectiveness and therefore should not interfere with business decisions: "One of the things that we'd always said to ourselves was that we would let rationality get the better of emotion, so if we saw something was not going to work, we wouldn't do it." Personal beliefs about emotions and ignorance about their potential resource creation benefits (in other words, causal ambiguity) can therefore explain (at least partially) sustainable competitive advantage.

Social resources can also be characterized by social complexity, which implies that they cannot always be systematically managed and influenced. According to Barney (1997, p. 157), "for the time being social engineering may be beyond the abilities of most firms." Our data support this view in that engineering of social resources through ER actions may be beyond the abilities or preferred strategies of some founders. Some founders (like Morten, the founder of INVEST), seem to prefer low-affect behavior. They regulate their rising emotions through suppressive strategies, which include denying the existence or importance of emotions, or refusing to talk or think about them (Butler et al., 2003; Matsumoto et al., 2008). In other words, ER is a socially complex task, and could therefore be difficult to imitate.

The extended framework shown in Figure 2 complements classic RBT in several aspects. First, it mitigates the concern about potential tautology (Priem and Butler, 2001, p. 28) by conceptualizing founders' ER actions, social resources (e.g., discretionary support and persistence from founders) and outcomes (economic value) independently, so that any analytic statement relating these concepts to each other will not be true by definition. Emotion regulation could help explain the creation of social resources with desirable properties, such as social complexity or causal ambiguity (see Barney, 1997). Put differently, expectations and luck (Barney, 1986) or accumulation over time (Dierickx and Cool, 1989) may not be the only mechanisms that help managers recognize and realize the value of key resources. ER provides another way of creating these resources. 
Second, our theory is inherently dynamic. We consider founders' performance of emotionrelated actions and how they influence the emergence of resource heterogeneity. By doing so, we address one of the key challenges of RBT, which is answering the "how" questions. Our study gets us one step closer to understanding "how the resources generate sustainable rents, other than through their heterogeneity" (Priem and Butler, 2001, p. 33). Echoing Feldman's (2004) theory of resource dynamics during internal organizational change, we show that social resources in a firm-building context can be viewed as "mutable sources of energy" (Feldman, 2004, p. 295). But in contrast to Feldman, who found that changes in organizational processes (interpreted as actions) could take one kind of resource (e.g., self-contained intra-unit network) and recreate it as a different resource (e.g., inter-unit network), our research focuses on the social resources that can be created de novo by the founders and other venture stakeholders.

\section{Summary of Contributions and Future Research}

Our research ties into recent work on resource management (e.g., see Holcomb, Holmes and Connelly, 2009; Sirmon, Hitt, and Ireland, 2007). By showing how founders deal with their emotions, and that this matters critically for the building of new organizations, our study also adds to the emerging research stream on affect in entrepreneurship (e.g., Baron, 2007, 2008; Shepherd and Cardon, 2009) and provides a fine-grained understanding of how opportunities are created (Alvarez and Barney, 2007).

Our study also raises a number of intriguing questions that could be investigated in future research. What other emotion-based mechanisms foster the creation of heterogeneous resources? How generalizable are the findings from this study across young firms (e.g., in a larger sample), across cultures (e.g., in countries other than the United Kingdom), and across firm types (e.g., in more established firms)? And how do founders' emotions, ER actions, and the process of firm formation co-evolve over time? Longitudinal, process research may complement hypothesis-testing studies in further illuminating these issues.

To conclude, our research provides insight into the origins of firms' resource-based strategy by linking founders' emotion-related behaviors to resource creation at the firm level. We hope that this research will spark more work on the micro-foundations of resource-based strategy to enhance our understanding of how firm founders and managers lay the foundations for value creation and future rents. 


\section{References}

Agrawal, N., Menon, G., and Aaker, J. L. (2007), "Getting emotional about health," Journal of Marketing Research, 44 (1), pp. 100-113.

Aldrich, H. E. and Ruef, M. (2006), “Organizations evolving,” Sage: London.

Alvarez, S. and Barney, J. (2007), "Discoveries and creation: Alternative theories of entrepreneurial action," Strategic Entrepreneurship Journal, 1, pp. 11-26.

Alvarez, S. and Busenitz, L. W. (2001), "The entrepreneurship of resource-based theory," Journal of Management, 27, pp. 755-775.

Amit, R., MacCrimmon, K. R., Zietsma, C., and Oesch, J. M. (2000), "Does money matter? Wealth attainment as the motive for initiating growth-oriented technology ventures," Journal of Business Venturing, 16, pp. 119-143.

Amit, R. and Schoemaker, P. J. (1993), "Strategic assets and organizational rent," Strategic Management Journal, 14, pp. 33-46.

Barney, J. B. (1986), "Strategic factor markets: Expectations, luck and business strategy," Management Science, 42, pp. 1231-1241.

Barney, J. B. (1991), "Firm resources and sustained competitive advantage," Journal of Management, 17, pp. 99-120.

Barney, J. B. (1997), "Gaining and Sustaining Competitive Advantage," Addison-Wesley Publishing Company: Reading, MA.

Barney, J. B. (2001), "Is the resource-based "view" a useful perspective for strategic management research? Yes," Academy of Management Review, 26, pp. 41-56.

Barney, J. B., Wright, M., and Ketchen, D. J. (2001), "The resource-based view of the firm: Ten years after 1991," Journal of Management, 27, pp. 625-641.

Baron, R. A. (2007), "Behavioral and cognitive factors in entrepreneurship: Entrepreneurs as the active element in new venture creation," Strategic Entrepreneurship, 1, pp. 167-182.

Baron, R. A. (2008), "The role of affect in the entrepreneurial process," Academy of Management Review, 33, pp. 328-340.

Baron, R. A. and Markman, G. D. (2000), "Beyond social capital: How social skills can enhance entrepreneurs' success,” Academy of Management Executive, 14, pp. 106-116.

Baron, R. A. and Markman, G. D. (2003), "Beyond social capital: the role of entrepreneurs' social competence in their financial success," Journal of Business Venturing, 18, pp. 41-60.

Baum, J. R. and Locke, E. A. (2004), "The relationship of entrepreneurial traits, skill and motivation to subsequent venture growth," Journal of Applied Psychology, 89 (4), pp. 587-598.

Baum, J. R., Locke, E. A., and Smith, K. G. (2001), "A multidimensional model of venture growth," Academy of Management Journal, 44 (2), pp. 292-303. 
Boyd, D. and Gumpert, D. (1984), "Coping with entrepreneur stress," Harvard Business Review, 61 (2), pp. 44-47.

Busenitz, L. W. and Barney, J. B. (1997), "Differences between entrepreneurs and managers in large organizations: Biases and heuristics in strategic decision-making," Journal of Business Venturing, 12, pp. 9-30.

Butler, E. A., Egloff, B., Wilhelm, F. H., Smith, N. C., Erickson, E. A., and Gross, J. J. (2003), "The social consequences of expressive suppression," Emotion, 3, pp. 48-67.

Cardon, M. S., Wincent, J., Singh, J., and Drnovsek, M. (2009), "The nature and experience of entrepreneurial passion," Academy of Management Review, 34 (3), pp. 511-532.

Castanias, R. F. and Helfat, C. E. (2001), "The managerial rents model: Theory and empirical analysis," Journal of Management, 27 (6), pp. 661-678.

Chen, X. P., Yao, X., and Kotha, S. (2009), "Entrepreneur passion and preparedness in business plan presentations: A persuasion analysis of venture capitalists' funding decisions," Academy of Management Journal, 52 (1), pp. 199-214.

Comegys, C. (1976), "Cognitive dissonance and entrepreneurial behavior," Journal of Small Business Management, 14 (1), pp. 1-6.

Côté, S. (2005), "A social interaction model of the effects of emotion regulation on work strain," Academy of Management Review, 30, pp. 509-530.

Deci, E. L. (1975), “Intrinsic Motivation,” Plenum Press: New York \& London.

Delmar, F. and Shane, S. (2004), "Legitimating first: organizing activities and the survival of new ventures," Journal of Business Venturing, 19 (3), pp. 385-410.

Dierickx, I. and Cool, K. (1989), "Asset stock accumulation and sustainability of competitive advantage,” Management Science, 35, pp. 1,504-1,511.

Dirks, K. T. and Ferrin, D. L. (2001), "The role of trust in organizational settings," Organization Science, 12, pp. 450-467.

Dorfman, P., Hanges, P., and Brodbeck, F. (2004), "Leadership and culture variation: the identification of culturally endorsed leadership profiles," In "Leadership, culture and organizations: the GLOBE study of 62 societies," House, R. J., Hanges, P. J., Javidan, M., Dorfman, P. W., and Gupta, V. (eds.), Sage: Thousands Oaks, CA, pp. 669-719.

Eisenberg, N. (2000), "Emotion, regulation, and moral development," Annual Review of Psychology, pp. 665-697.

Eisenhardt, K. M. (1989), "Building theories from case study research," Academy of Management Review, 14, pp. 532-550.

Eisenhardt, K. M. and Graebner, M. E. (2007), "Theory building from cases: opportunities and challenges," Academy of Management Journal, 50, pp. 25-32.

Feldman, M. S. (2004), "Resources in emerging structures and processes of change," Organization Science, 15 (3), pp. 295-309. 
Foss, K. and Foss, N. J. (2005), "Resources and transaction costs: how property rights economics furthers the resource-based view,” Strategic Management Journal, 26, pp. 541-553.

Fredrickson, B. L. (1998), "What good are positive emotions?," Review of General Psychology, 2, pp. 300-319.

Frijda, N. H. (1986), "The emotions," Cambridge University Press and Editions de la Maison des Sciences de l'Homme: Cambridge NY, Paris.

Furr, R. M. and Funder, D. C. (1998), “A multimodal analysis of personal negativity,” Journal of Personality \& Social Psychology, 74 (6), pp. 1580-1591.

Gartner, W. B. (1985), “A conceptual framework for describing the phenomenon of new venture creation," Academy of Management Review, 10 (4), pp. 696-706.

Ghoshal, S. (2005), "Bad management theories are destroying good management practices," Academy of Management Learning \& Education, 4 (1), pp. 75-91.

Gimeno, J., Folta, T. B., Cooper, A. C., and Woo, C. Y. (1997), "Survival of the fittest? Entrepreneurial human capital and the persistence of underperforming firms," Administrative Science Quarterly, 42 (4), pp. 750-783.

Goss, D. (2005a), "Schumpeter's legacy? Interaction and emotions in the sociology of entrepreneurship," Entrepreneurship Theory and Practice, 29 (2), pp. 205-218.

Goss, D. (2005b), "Entrepreneurship and 'the social': towards a deference-emotion theory," Human Relations, 58 (5), pp. 617-636.

Gottschalg, 0. and Zollo, M. (2007), "Interest alignment and competitive advantage," Academy of Management Review, 32 (2), pp. 418-437.

Grandey, A. A. (2003), "When 'the show must go on': Surface acting and deep acting as determinants of emotional exhaustion and peer-rated service delivery," Academy of Management Journal, 46, pp. 86-96.

Gross, J. J. (1999), "Emotion regulation: past, present, future," Cognition \& Emotion, 13 (5), pp. 551-573.

Gross, J. J. and John, O. P. (2003), "Individual differences in two emotion regulation processes: Implications for affect, relationships and well-being," Journal of Personality \& Social Psychology, 85 (2), pp. 348-362.

Gumpert, D. and Boyd, D. (1984), "The loneliness of the small business owner," In "Designing and managing your career," Levinson H. (eds.), Harvard Business School Press: Boston, MA, pp. 289-296.

Hatfield, E., Cacioppo, J. T., and Rapson, R. L. (1994), "Emotional contagion," Cambridge University Press and Editions de la Maison des sciences de l'homme: Cambridge [England]; New York, Paris.

Helfat, C. and Peteraf, M. A. (2009), "Cognitive capabilities and the entrepreneurial management components of dynamic capabilities," Working paper, Dartmouth College, Hanover, NH. 
Hitt, M. A. and Ireland, R. D. (2000), "The intersection of entrepreneurship and strategic management research, In Handbook of entrepreneurship," Sexton, D. L. and Landstrom, H. (eds.), Blackwell, Oxford, pp. 45-63.

Hochschild, A. R. (1983), “The managed heart: Commercialization of human feeling," University of California Press, Berkeley, CA.

Holcomb, T. R., Holmes, R. M. Jr., and Connelly, B. L. (2009), "Making the most of what you have: Managerial ability as a source of resource value creation," Strategic Management Journal, 30, pp. 457-485.

House, R. J., Hanges, P. M., Javidan, M., Dorfman, P., and Gupta, V. (2004), "Culture, leadership, and organizations: the GLOBE study of 62 societies," Sage: Thousands Oaks, CA.

Javidan, M., Dorfman, D., Sully de Luque, M., and House, R. J. (2006), "In the eye of the beholder: cross-cultural lessons in Leadership from project GLOBE," Academy of Management Perspectives, 20 (1), pp. 67-90.

Jensen, M. C. and Meckling, W. H. (1976), "Theory of the firm: Managerial behavior, agency costs and ownership structure," Journal of Financial Economics, 3 (4), pp. 305-360.

Kaplan, S. N. and Strömberg, P. (2003), "Financial contracting theory meets the real world: An empirical analysis of venture capital contracts," Review of Economic Studies, 70 (243), pp. 281-315.

Keltner, D., Ekman, P., Gonzaga, G. C., and Beer, J. (2003), "Facial expressions of emotions," In "Handbook of affective sciences," Davidson, R. J., Scherer, K. R., and Goldsmith, H. H. (eds.), New York: Oxford University Press, pp. 415-432.

Lazarus, R. S. (1991), "Progress on a cognitive-motivational-relational theory of emotion," American Psychologist, 46 (8), pp. 819-834.

Lerner, J. S. and Keltner, D. (2001), "Fear, anger, and risk," Journal of Personality \& Social Psychology, 81 (1), pp. 146-159.

Lewis, M. W. (2000), "Exploring the paradox: toward a more comprehensive guide," Academy of Management Review, 25 (4), pp. 760-776.

Lopes, P., Côte, S., and Salovey, P. (2005), "An ability model of emotional intelligence: Implications for assessment and training," In "Linking emotional intelligence and performance at work," Druskat, V. U., Sala, F. , and Mount, G. (eds.), Mahwah, NJ: Erlbaum, pp. 53-80.

Luque, M. S., Washburn, N. T., Waldman, D. A., and House, R. J. (2008), "Unrequited profit: how stakeholder and economic values relate to subordinates' perceptions of leadership and firm performance," Administrative Science Quarterly, 53 (4), pp. 626-654.

Lüscher, L. S. and Lewis, M. W. (2008), "Organizational change and managerial sensemaking: working through paradox," Academy of Management Journal, 51 (2), pp. 221-240.

MacMillan, I. C., Siegel, R., Narasimha, P., and Subba, N. (1985), “Criteria used by venture capitalists to evaluate new venture proposals," Journal of Business Venturing, 1 (1), pp. 119-128.

Mahoney, J. T. and Pandian, J. R. (1992), "The resource-based view within the conversation of strategic management," Strategic Management Journal, 13, pp. 363-380. 
Matsumoto, D., Seung, H. Y., and Nakagawa, S. (2008), "Culture, emotion regulation, and adjustment,” Journal of Personality and Social Psychology, 94 (6), pp. 925-937.

Mayer, R. C., Davis, J. H., and Schoorman, F. D. (1995), “An integrative model of organizational trust,” Academy of Management Review, 20 (3), pp. 709-734.

Mayer, J. D. and Salovey, P. (1997), "What is emotional intelligence?," In "Emotional development and emotional intelligence: Implication for educators," Salovey, P., and Sluyter, D. (eds.), New York, Basic Books.

McMullen, J. S. and Shepherd, D. A. (2006), "Entrepreneurial action and the role of uncertainty in the theory of the entrepreneur," Academy of Management Review, 31 (1), pp. 132-152.

Nelson, R. R. (1991), "Why do firms differ and how does it matter?," Strategic Management Journal, 12 (S2), pp. 61-74.

Ortony, A., Clore, G. L., and Collins, A. (1988), "The cognitive structure of emotions," Cambridge University Press: Cambridge, UK.

Perry-Smith, J. E. and Coff, R. W. (2009), "Navigating a Darwinian process of entrepreneurial creativity: How optimal group mood differs for generating and selecting creative business ideas," Working paper, Emory University, Atlanta, Georgia.

Peteraf, M. A. (1993), "The cornerstones of competitive advantage: A resource-based view," Strategic Management Journal, 14, pp. 179-192.

Peteraf M. A. and Barney, J. B. (2003), “Unraveling the resource-based tangle," Managerial \& Decision Economics, 24 (4), pp. 309-323.

Pratt, M. (2009), "For the lack of a boilerplate: tips on writing up (and reviewing) qualitative research," Academy of Management Journal, 52 (5), pp. 856-862.

Priem, R. and Butler, J. E. (2001), "Is the resource-based "view" a useful perspective for strategic management research?," Academy of Management Review, 26 (1), pp. 22-40.

Robinson, M. D. and Clore, G. L. (2002), "Episodic and semantic knowledge in emotional selfreport: evidence from two judgment processes," Journal of Personality \& Social Psychology, 83 (1), pp. 198-215.

Roseman, I. J. (1991), “Appraisal determinants of discrete emotions,” Cognition \& Emotion, 5 (3), pp. 161-200.

Rumelt, R., Schendel, D., and Teece, D. (1994), "Fundamental Issues in Strategy: A Research Agenda," Harvard Business School Press, Boston, MA.

Shepherd, D. A. (1999), "Venture capitalists' assessment of new venture survival," Management Science, 4 (5), pp. 621-632.

Shepherd, D. A. (2003), "Learning from business failure: Propositions of grief recovery for the self-employed," Academy of Management Review, 28 (2), pp. 318-329.

Shepherd, D. A. and Cardon, M. S. (2009), "Negative emotional reactions to project failure and the self-compassion to learn from the experience," Journal of Management Studies, 46 (6), pp. 923-949. 
Sirmon, D. G., Hitt, M. A., and Ireland, R. D. (2007), "Managing firm resources in dynamic environments to create value: Looking inside the black box," Academy of Management Review, 32, pp. 273-292.

Strauss, A. L. and Corbin, J. M. (1998), "Basics of qualitative research: techniques and procedures for developing grounded theory," Sage: Thousand Oaks, CA.

Suddaby, R. (2006), "What grounded theory is not," Academy of Management Journal, 49 (4), pp. 633-642.

Van Maanen, J. (1979), "Reclaiming qualitative method for organizational research: a preface," Administrative Sciences Quarterly, 24 (2), pp. 520-526.

Webster, F. A. (1976), "A model for new venture creation: A discourse on rapacity and the independent entrepreneur," Academy of Management Review, 1 (1), pp. 26-37.

Whitener, E. M., Brodt, S. E., Korsgaard, M. A., and Werner J. M. (1998), “Managers as initiators of trust: an exchange relationship framework for understanding managerial trustworthy behavior," Academy of Management Review, 23 (3), pp. 513-530.

Williams, J. R. (1994), "Strategy and the search for rents: the evolution of diversity among firms, in Fundamental issues in strategy,” Rumelt R., Schendel, D., and Teece, D. (eds.), Harvard Press, Cambridge, M. A., pp. 229-246.

Yin, R. K. (1994), “Case study research: Design and methods," Sage, Thousand Oaks, CA.

Yulk, G. (2006), “Leadership in organizations,” Prentice Hall, Upple Saddle River, NJ. 


\section{Appendix}

Two In-depth Examples of Founders' Emotion Regulation Actions

\section{Managing Boredom from Slow Venture Development}

When we interviewed entrepreneurs, we expected to catch them at a particularly busy time of their lives. After all, creating a new firm involves many time-consuming tasks (Aldrich and Ruef, 2006; Delmar and Shane, 2004). Therefore, we were surprised to find that some entrepreneurs experienced boredom due to long periods of down-time or slower-than-expected venture development. Some founders took deliberate action to deal with this unpleasant emotion and reduce it. Interestingly, these entrepreneurs did not perform personal activities (e.g., sports, music, other hobbies) to regulate their work-related boredom, but enacted killingtwo-birds-with-one-stone actions that reduced their boredom and simultaneously helped firmbuilding (e.g., through the reformulation of their firm's strategy). This managing boredom from slow venture development helped founders stay focused on the current development needs of their young firms despite their feeling that it might be psychologically tedious.

CONSULT, for example, went through a phase of slow growth about two years after its inception, due to a sharp slowdown in demand in its particular product-market niche. The senior executives of the firm deliberated whether they should adapt to the changed business environment by adopting a strategy of zero growth, and focusing on being profitable instead, but decided against it because this would have been too boring for the management team. Sam, the co-founder, explained:

"Having a small, profitable business is very nice, but at the end of the day, I think we'd all get too bored with it. So we decided that gentle growth is the right thing. Try a few things, don't spend any silly amounts of money, stay profitable, and increase revenues at a reasonable rate. Also, we'll be looking for new lines of business, and we'll be looking to extend our current lines of business." (Founder, CONSULT)

Thus, in order to reduce or even avoid feeling boredom, the founders decided to grow their venture, despite the unfavorable business environment for that type of strategy. The founder's ER behavior entailed a mobilization of his personal resolve to achieve the new organizational goal. It had important organizational implications in terms of social resources created (from self, and from other members of the management team that he led, as suggested by the use of "we") to support the adopted growth strategy for the venture. Interestingly, this ER action also influenced the various means used by the founder to pursue growth, namely through innovation as well as market share increases in existing business lines (as opposed to cost cutting, for example). Interviews conducted within CONSULT suggest that firm members were excited by innovation and pursuing multiple lines of business.

Another founder, Lars of INCUBATE, also experienced boredom because of the small scale of his venture. In contrast to CONSULT, however, his response was to keep operating on a small scale and focus on becoming profitable. In doing so, however, he let boredom erode his personal interest in the firm over time and eventually abandoned the venture.

"We had a turnover of about, I suppose, $€ 5$ million. That's small, and most of what you're dealing with on a day-to-day basis is, you know, whether your warehouse manager is off sick and whether there's been a flood in the back of the office, or whatever. Frankly for me, not terribly motivating seeing this compared with the excitement that I've had in the 
previous three years... So that was the point where I was essentially deciding that I was probably going to move myself out of the business." (Founder, INCUBATE)

Lars did not perform the kinds of ER action that would have allowed him to manage his boredom from slow venture development while at the same time continuing with the venturing activity. As a result, his motivation to persist declined and the venture lost one of its founding members.

\section{Emotional Expanding During Organization Building}

Our data showed that some founders became emotionally attached to new targets that emerged during the organization building process. To illustrate, some founders developed a new concern for the welfare of employees and their families, a concern that did not seem salient or important to them when they first created their firms. When this concern was added to their original desire to create personal wealth, we called this behavior "emotional expanding," because this ER action increased the variety of founders' emotion-related benefits associated with building the venture. These additions complemented founders' focus on economic benefits. Our data also suggest that this particular ER behavior could produce important social resource creation benefits for the firm, for example, when this attachment led founders to devote a high amount of their time, energy, creativity, and efforts to the new firm.

To illustrate the concept of emotional expanding, some entrepreneurs developed a passion (Cardon et al., 2009) for the venture's product or service. James, the co-founder of BUDGET, had worked for a venture capital firm before becoming an entrepreneur. He had not been interested in the hotel business. When we asked him why he had started his business in the particular productmarket domain of budget hotels, he replied that he had, "no emotional attachment for budget hotels. I am not passionate about budget hotels. But I am passionate about the fact that there is a wonderful value creation opportunity there." Three years after this first interview with us, James had become emotionally passionate about budget hotels. He had added the passion for the hotel business to his passion for building a value-creating venture:

"I am really passionate about building a venture. You know, I'm not going to say that the venture could be in anything, because clearly that's not true. I'm passionate about hotels. I want them to be the best they can be." (Founder, BUDGET)

As the quote suggests, adding a new object for his passion motivated James to create the best possible product ("the best they can be"). This ER action generated personal energy and creativity for developing the venture's new offerings - all important social resources for the young firm.

In another case, Sam, the co-founder of CONSULT, mentioned during his first interview with us that he enjoyed that his business gave him, "a real opportunity to be enthusiastic, because I love being enthusiastic about things." The object of Sam's attachment in the early days of the venture was clearly the venture creation opportunity (a somewhat abstract concept) itself. Later, Sam discovered the joy of being responsible for other people and of arranging his time flexibly. He added these new-found objects of emotional attachment to his existing ones. As he elaborated:

"I enjoy the responsibility of having an organization, of paying mortgages and school fees for twenty-two other people. I do enjoy that. I enjoy the fact that I can choose on a day- 
to-day basis what I do. I can be flexible with my time... But I'm going to put more than double back in." (Founder, CONSULT)

Sam experienced true joy in assuming responsibility for the livelihood of his employees' families and the temporal freedom of the entrepreneur. That joy reinforced the emotional payoff he would receive from his firm-building activity, and it contributed to his making extraordinary efforts, in terms of time spent working for the venture ("put more than double back in"). This example again suggests a causal link between the founder's ER action (here: emotional expanding), and creation of social resources for the firm (here: level of effort put in by the founder). 